\title{
Synthesis, Spectroscopic, and Theoretical Study of Copper and Cobalt Complexes with Dacarbazine
}

\author{
Grzegorz Świderski ${ }^{1} *{ }^{\circledR}$, Ryszard Łaźny ${ }^{2}$, Michał Sienkiewicz ${ }^{2}$, Monika Kalinowska ${ }^{1}$, Renata Świsłocka ${ }^{1}($, \\ Ali Osman Acar ${ }^{3}$, Aleksandra Golonko ${ }^{4}{ }^{\mathbb{D}}$, Marzena Matejczyk ${ }^{1}$ and Włodzimierz Lewandowski ${ }^{1, *}$ \\ 1 Department of Chemistry, Biology and Biotechnology, Bialystok University of Technology, Wiejska Street 45E, \\ 15-351 Bialystok, Poland; m.kalinowska@pb.edu.pl (M.K.); r.swislocka@pb.edu.pl (R.Ś.); \\ m.matejczyk@pb.edu.pl (M.M.) \\ 2 Faculty of Chemistry, University of Bialystok, Ciolkowskiego Street 1K, 15-245 Bialystok, Poland; \\ lazny@uwb.edu.pl (R.Ł.); mikes@uwb.edu.pl (M.S.) \\ 3 Material Science and Nanotechnology Engineering, TOBB University of Economics and Technology, \\ 06-560 Ankara, Turkey; aacar@etu.edu.tr \\ 4 Institute of Agricultural and Food Biotechnology, Department of Microbiology, Rakowiecka 36, \\ 02-532 Warsaw, Poland; olau.95@gmail.com \\ * Correspondence: g.swiderski@pb.edu.pl (G.Ś.); w.lewandowski@pb.edu.pl (W.L.)
}

\section{check for}

updates

Citation: Świderski, G.; Łaźny, R.; Sienkiewicz, M.; Kalinowska, M.;

Świsłocka, R.; Acar, A.O.; Golonko,

A.; Matejczyk, M.; Lewandowski, W.

Synthesis, Spectroscopic, and

Theoretical Study of Copper and

Cobalt Complexes with Dacarbazine.

Materials 2021, 14, 3274. https://

doi.org/10.3390/ma14123274

Academic Editors: Nicola Margiotta and Edward Szlyk

Received: 16 April 2021

Accepted: 10 June 2021

Published: 13 June 2021

Publisher's Note: MDPI stays neutral with regard to jurisdictional claims in published maps and institutional affiliations.

Copyright: (c) 2021 by the authors. Licensee MDPI, Basel, Switzerland. This article is an open access article distributed under the terms and conditions of the Creative Commons Attribution (CC BY) license (https:/ / creativecommons.org/licenses/by/ $4.0 /)$.
Abstract: Dacarbazine (DAC) 5-(3,3-dimethyl-1-triazenyl)imidazole-4-carboxamide is an imidazolecarboxamide derivative that is structurally related to purines. DAC belongs to the triazene compounds, which are a group of alkylating agents with antitumor and mutagenic properties. DAC is a non-cell cycle specific drug, active in all phases of the cellular cycle. In the frame of this work the $3 \mathrm{~d}$ metal complexes (cobalt and copper) with dacarbazine were synthesized. Their spectroscopic properties by the use of FT-IR, FT-Raman, and ${ }^{1} \mathrm{HNMR}$ were studied. The structures of dacarbazine and its complexes with copper(II) and cobalt(II) were calculated using DFT methods. The effect of metals on the electronic charge distribution of dacarbazine was discussed on the basis of calculated NBO atomic charges. The reactivity of metal complexes in relation to ligand alone was estimated on the basis of calculated energy of HOMO and LUMO orbitals. The aromaticity of the imidazole ring in dacarbazine and the complexes were compared (on the basis of calculated geometric indices of aromaticity). Thermal stability of the investigated 3d-metal complexes with dacarbazine and the products of their thermal decomposition were analyzed.

Keywords: dacarbazine; triazene; anticancer properties; 3d metal complexes; spectroscopy (IR, Raman); NMR

\section{Introduction}

Dacarbazine (DAC) [5-(3,3-Dimethyl-1-triazenyl) imidazole-4-carboxamide] belongs to the alkylating agents of triazene group use in anticancer therapy [1-4]. DAC is an imidazole-carboxamide derivative that is structurally related to purines. DAC is a noncell cycle specific drug, active in all phases of the cellular cycle. This drug is used for chemotherapy in different types of cancer malignant melanoma, soft-tissue sarcoma, osteogenic sarcoma, neuroblastomas, and Hodgkin's disease [5,6]. The detailed molecular mechanism of DAC activity is unclear. Research to date indicates three possible mechanisms of action of this drug: (a) inhibition of DNA synthesis by acting as a purine analog, (b) action as alkylating agent, and (c) interaction with SH groups [7]. Hayward et al. [8], proposed another mechanism of DAC activity based on antimetabolite-like activity. In this mechanism, DAC plays the role of an inhibitor of purinic base incorporation into DNA during DNA synthesis. However, this mechanism does not seem to play a key role in the antitumor activity of DAC [8].

Based on experimental data it seems that alkylation of nucleic acid is the primary mode of antitumor DAC action [7]. DAC as an alkylator donates methyl groups to many sites 
in DNA. A very common place of attack of DAC is the $\mathrm{O}(6)$-position of guanine resulting in $\mathrm{O}(6)$-methylguanine $(\mathrm{O}(6)-\mathrm{MeG})$ which frequently mispairs with thymine during DNA duplication. Each cell is equipped with repair systems, the mismatch repair (MMR) system recognizes $\mathrm{O}(6)-\mathrm{MeG}$ :T mismatches which lead to cell cycle arrest and cell death. If MMR is defective, the cell will divide and GC $\rightarrow$ AT transition mutations occur (Figure 1) [5,6]. Generally, DAC causes DNA damage, cell cycle arrest and apoptosis [9]. Hayward et al. [8] proposed another mechanism of DAC activity based on antimetabolite-like activity. In this mechanism, DAC plays the role of an inhibitor of purinic base incorporation into DNA during DNA synthesis. However, this mechanism does not seem to play a key role in the antitumor activity of DAC [8]. DAC is a prodrug that is activated by N-demethylation in liver microsomes with participation of the liver's microsomal enzymes (CYP1A1, CYP1A2, and CYP2E1) that hydroxilate and N-demethylate the DAC [7].
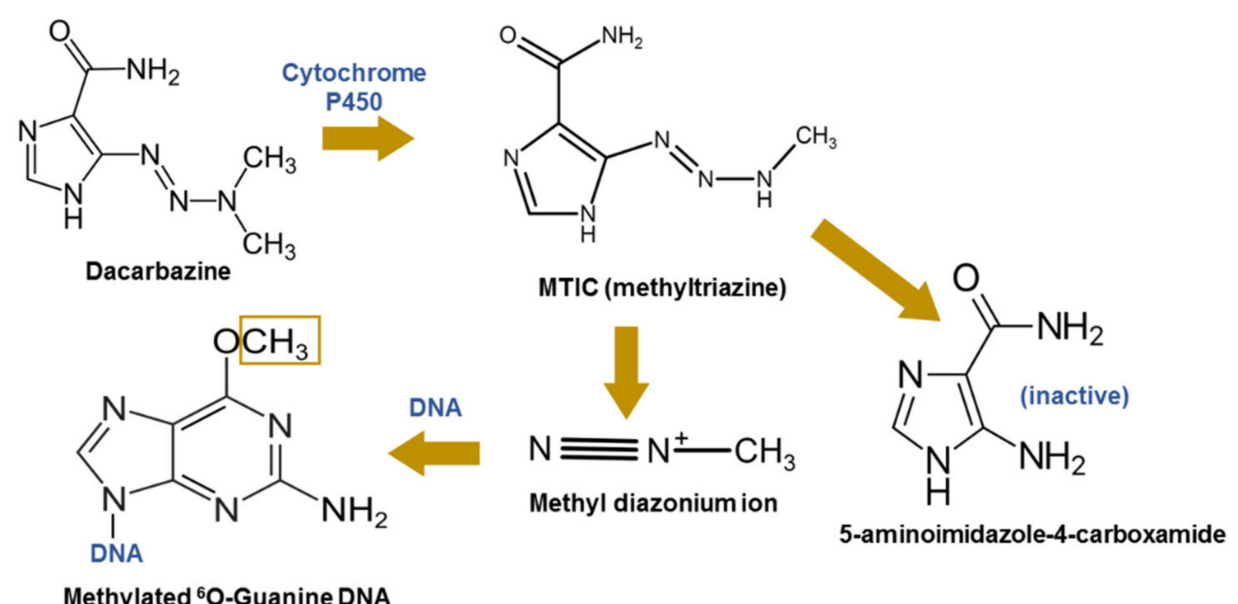

Figure 1. Mechanism of action of dacarbazine.

Studies by earlier authors have shown that DAC, in combination with other drugs is used for treating renal adenocarcinoma, soft-tissue sarcoma and malignant lymphomas. Al-Qatati and Aliwaini [9] in their work, presented that combined pitavastatin with DAC treatment induces cell death through intrinsic apoptosis in melanoma cells. Naserian et al. [10] investigated the cytotoxicity and apoptosis of the metformin alone and in combination with DAC in Raji and Ramos lymphoma cell lines. Metformin showed synergistic cytotoxic effects in combination with DAC, reduced cell viability, and increased apoptosis in Raji and Ramos lymphoma cells in comparison with the use of each drug alone. Additionally, Finotello et al. [11] reported that results of in vitro and in vivo studies suggest that dacarbazine acts synergistically with anthracyclines and has a moderate effect on the treatment of high-grade sarcomas in humans.

The greatest obstacle in the treatment of patients with advanced stages of melanoma and other cancers is the unique tumor resistance, both primary and secondary, to all known compounds including dacarbazine. The complexation of metal ions with anticancer drugs creates the possibility of an increase in the bioavailability and activity of drugs [12,13]. Metal complexes play a very important role in modern cancer therapy. The complexation of metal ions with biologically active ligands can change their therapeutic activity. Metal ions affect the distribution of the electronic system of ligands which in turn changes the reactivity and biological activity of the ligands [14,15]. Complexes with some of the transition metals, e.g., $\mathrm{Au}, \mathrm{Ag}, \mathrm{Co}, \mathrm{Cu}, \mathrm{Ni}, \mathrm{Fe} \mathrm{Pt}(\mathrm{II})$ and (IV), $\mathrm{Pd}(\mathrm{II})$, and $\mathrm{Ru}(\mathrm{III})$ show high anticancer activity [16].

DAC possesses a triazene group connected to the imidazole ring which is attached to the carboxamide group. In the structure of the DAC, they are atoms that may be donors of electron pairs, making complexation of the ligand with metal ions possible. Different types of metal-ligand complexes can be formed when the molecule of dacarbazine coordinates metal through seven potential donor atoms. 
Several studies have shown that complexation of dacarbazine with metal ions may change the reactivity and stability of the molecule, thereby improving its therapeutic properties. In vitro and in vivo studies have shown that the iron(III) complex of dacarbazine may exhibit an increased antitumor effect compared to the ligand alone [17,18]. Temerk and Ibrahim [19] in their work investigated the influence of DAC complexation with $\mathrm{Cu}$ (II) on the drug intercalation to DNA. The results of that experiment showed that the interaction of DAC with dsDNA in the presence of $\mathrm{Cu}(\mathrm{II})$ led to a much stronger intercalation, compared to DAC alone [19].

Our studies showed that there is a dependency between the electronic charge distribution in metal complex and salt molecules and the location of these metals in the periodic table [20]. Alkali metal cations and some heavy metal cations ( $\mathrm{Ag}(\mathrm{I}), \mathrm{Pb}(\mathrm{II}), \mathrm{Hg}(\mathrm{I}), \mathrm{Hg}(\mathrm{II})$ ) perturb the electronic system of ligands (benzoic, salicylic, pyridinecarboxylic acids and others), whereas $3 \mathrm{~d}$ and $4 \mathrm{f}$ metal cations stabilize it [21-26]. This conclusion allows us to foresee the changes in the electronic structure under the influence of metal cations and estimation of the physicochemical and biological properties of complexes. Thermal analysis allows us to determine the thermal stability of the investigated metal complexes and to determine the residues of this process. We have repeatedly tested the thermal stability of ligands of high biological importance and their complexes with metals. We found that metal oxides are the final product of the decomposition of metal complexes under the oxygen conditions of the process, with the use of a sufficiently high temperature [27-31]. This may be of practical importance when thermal disposal of drugs based on metal complexes with particularly toxic ligands, such as dacarbazine, is used.

In the frame of this work the $3 \mathrm{~d}$ metal complexes with dacarbazine were synthesized. The aim of the work was to estimate the effect of metal ions (copper(II) and cobalt(II)) on the reactivity and electronic stability of dacarbazine. For this purpose, the spectroscopic properties of compounds were studied by the use of FT-IR, FT-Raman, and ${ }^{1} \mathrm{HNMR}$. Thermal stability of the investigated 3d-metal complexes (cobalt(II) and copper(II)) with dacarbazine and the products of their thermal decomposition were analyzed.

Synthesis of complexes with metals such as copper and cobalt is a noticeable trend in many fields of science, such as pharmaceuticals and technologies related to catalysis and sensors. Padnya et al., with high efficiency, synthesized a series of catechol-containing Schiff bases, tetrasubstituted on the lower rim thiacalix [32] arene derivatives in three stereoisomeric forms, cone, partial cone and 1,3-alternate, which can be used as a component of antimicrobial agents, catalysts, chemical, and electrochemical sensors [32]. On the other hand, the copper complexes described by Colombo et al. can be applied as eco-sustainable redox mediators in sye-sensitized solar cells [33].

In the case of compounds with potential biological applications, it should be noted that some metal complexes with many oxidation states, e.g., vanadium, undergo many chemical transformations under physiological conditions. So the study of the mechanism of action should assume that the complexes do not exist in cells/tissues in its original form. The authors of the review suggest the necessity of speciation of the vanadium species formed in each biological compartment and defining the defined reaction conditions under which the complex compound acts [34]. This is especially important when assessing the interaction of such complexes with biological macromolecules, e.g., proteins or DNA. Currently, there are many inorganic coordination compounds used as antibiotics (bleomycin), in the treatment of neoplastic diseases (cisplatin) or anti-arthritis drugs (auranofin) [35]. Metal complexes also offer hope for a more effective treatment of solid tumors in which there is a hypoxic state with a more acidic and reducing environment. Studies on compounds containing $\mathrm{Pt}^{4+}, \mathrm{Ru}^{3+}$, and $\mathrm{Co}^{3+}$ have shown the potential for selective action in cancer cells. Cobalt, unlike ruthenium or platinum, is non-toxic and, when reduced from $\mathrm{Co}^{3+}$ to $\mathrm{Co}^{2+}$ under hypoxic conditions, the complex becomes labile, which enables drug dissociation. In experimental research, de Souza et al. proposed cobalt(III) L-Phe complexes as a model for the hypoxia-activated delivery of melphalan [36]. 


\section{Materials and Methods}

\subsection{Synthesis}

Complexes dacarbazine- $\mathrm{CoCl}_{2}(\mathrm{DAC})_{2} * 1.75 \mathrm{CH}_{3} \mathrm{OH}$ and $\mathrm{CuCl}_{2}(\mathrm{DAC})_{2} * 1.5 \mathrm{CH}_{3} \mathrm{OH}$ were obtained by the same method of synthesis by reaction dacarbazine of metal chlorides in a methanolic medium. The weight amount of dacarbazine $(0.2 \mathrm{~mol})$ was dissolved in cold methanol and it was added to $5 \mathrm{~mL}$ of methanolic solution of metal chloride $(0.1 \mathrm{~mol})$ $\left(\mathrm{CuCl}_{2}, \mathrm{CoCl}_{2}\right)$. Then the mixture was shaken for $2 \mathrm{~h}$ in the water bath in room temperature. Next, $50 \mathrm{~mL}$ of diethyl ether was added and it was left for $2 \mathrm{~h}$. The precipitate was washed three times with $50 \mathrm{~mL}$ of diethyl ether. The obtained complexes were dried in a vacuum for $72 \mathrm{~h}$.

Elemental analysis: Anal. Calc. for $\mathrm{CoCl}_{2}(\mathrm{DAC})_{2}{ }^{*} 1.75 \mathrm{CH}_{3} \mathrm{OH}: \mathrm{C}, 29.62 ; \mathrm{H}, 4.75 ; \mathrm{N}$, 30.72. Found: C, 29.35; $\mathrm{H}, 5.03 ; \mathrm{N}, 30.318$. Calc. for $\mathrm{CuCl}_{2}(\mathrm{DAC})_{2}{ }^{*} 1.5 \mathrm{CH}_{3} \mathrm{OH}: \mathrm{C}, 29.98 ; \mathrm{H}$, $4.91 ; \mathrm{N}, 30.53$. Found: $\mathrm{C}, 30.13 ; \mathrm{H}, 5.30 ; \mathrm{N}, 30.82$.

\subsection{Methods}

The FT-IR spectra were recorded with an Alfa (Bruker) spectrometer (Billerica, MA, USA) within the range of $400-4000 \mathrm{~cm}^{-1}$. Samples in the solid state were measured in $\mathrm{KBr}$ matrix pellets and ATR technique. FT-Raman spectra of solid samples were recorded in the range of 100-4000 $\mathrm{cm}^{-1}$ with a MultiRam (Bruker) spectrometer (Billerica, MA, USA). The resolution of the spectrometer was $1 \mathrm{~cm}^{-1}$. The ${ }^{1} \mathrm{H}$ spectra of DMSO solution of studied compounds were recorded with a Bruker Avance II $400 \mathrm{MHz}$ (Billerica, MA, USA) unit at room temperature (sample content $5 \mathrm{mg} / 1 \mathrm{~mL}$ of solvent). TMS was used as an internal reference. Elemental analysis for the weight percentages of carbon and hydrogen was done with Perkin-Elmer 240 (Waltham, MA, USA) equipment. To calculate optimized geometrical structures, NMR and IR spectra, NBO analysis, HOMO/LUMO orbitals of dacarbazine, and complexes with copper and cobalt were used with the density functional (DFT) hybrid method B3LYP with nonlocal correlation provided by the Lee-Young-Parr expression. All calculations were carried out with $6-311++G(d, p)$ basis set and performed with GAUSSIAN 09 [37] packed.

The aromaticity indices (HOMA, GEO, EN, I6) were calculated for geometric structures (theoretical and calculated) of dacarbazine and its complexes. The HOMA index (harmonic oscillator model of aromaticity) differs from all other geometry-based ones by assuming another reference bond length. In this model, instead of the mean bond length a concept of the optimal bond length is applied [38]:

$$
H O M A=1-\left[\alpha\left(R_{o p t}-R_{a v}\right)^{2}+\frac{\alpha}{n} \sum\left(R_{a v}-R_{i}\right)^{2}\right]=1-E N-G E O
$$

Within the confines of the HOMA model, it is possible to obtain two components which describe different contributions to decrease in aromaticity, i.e., (a) due to bond elongation (the EN component), and (b) due to bond length alternation (the GEO component). The value of HOMA index is equal to 1 for the entire aromatic system; HOMA $=0$ when the structure is non-aromatic and $\mathrm{HOMA}<0$ for an anti-aromatic ring.

The value of the Bird's aromaticity index $\left(\mathrm{I}_{5}, \mathrm{I}_{6}\right)$ describes the equation [39]:

$$
I=100\left\{1-\left(\frac{V}{V_{k}}\right)\right\}
$$

where: $V_{k}$ is for the five-membered rings 35 and the six-membered 33.3, and $V$ is calculated from the equation:

$$
V=\left(\frac{100}{n_{a v}}\right)\left[\sum_{r=1}^{n}\left(n_{r}-n_{a v}\right)^{2} / n\right]^{1 / 2}
$$

where: $n_{a v}$-average binding order, $n$-bond order based on bond length: $n=(a / R)-b, a$ and $b$-parameters depending on the type of atoms in the bond. 
$\mathrm{NBO}$ analysis was performed for the optimized structures to determine the electronic charge distribution [40]. Calculations were made using the B3LYP/6-311++G(d, p) method.

Thermal analyses of the prepared complexes were performed by the thermogravimetric (TG) methods using the Perkin-Elmer analyzer in a dynamic air atmosphere. Therefore, $6.0-8.0 \mathrm{mg}$ samples were heated in the range of $50-890^{\circ} \mathrm{C}$ in the ceramic crucibles using a heating rate of $10^{\circ} \mathrm{C} \mathrm{min}^{-1}$. The products of dehydration and decomposition processes were determined from the TG curves.

The crystal structure of the DNA dodecamer was obtained from Protein Database (PDB ID: 1BDNA) and used for molecular modeling studies carried out in AutoDock 4.2 MGL Tools package supplied with AutoGrid4.0 and AutoDock4.0 [41]. In order to analyze the obtained results and compare the number of hydrogen bonds formed, the VMD (Visual Molecular Dynamics) program was used [42].

AutoGrid4.0 was used to compute grid maps using a grid box. The molecular docking was carried out by setting the grid box size to cover the predicted binding sites, using $52,56,118 \mathrm{x}, \mathrm{y}, \mathrm{z}$ points with a grid spacing of $0.375 \AA$. The grid center was set to 14.72 , $21.006,8.801 \mathrm{x}, \mathrm{y}$, and $\mathrm{z}$ dimensions, respectively. The Lamarckian genetic algorithm (LGA) was selected to generate the best ligand conformers. We successfully performed 1000 docking runs with AutoDock4.0 for each ligand (DAC1, DAC2) and Co(II)-DAC, Cu(II)DAC complexes. As standard values for hydrogen bond formation assumed distance $2.9 \AA$ and cutoff angle 60 degrees (120 to 180 degrees). To visualize results BIOVIA Discovery Studio and USCF Chimera 1.10.2 were used [43,44].

\section{Results and Discussion}

\subsection{IR and Raman Spectra}

The IR and Raman spectra of dacarbazine and IR spectra of cobalt(II) and copper(II) complexes of dacarbazine are shown in Figure 2.

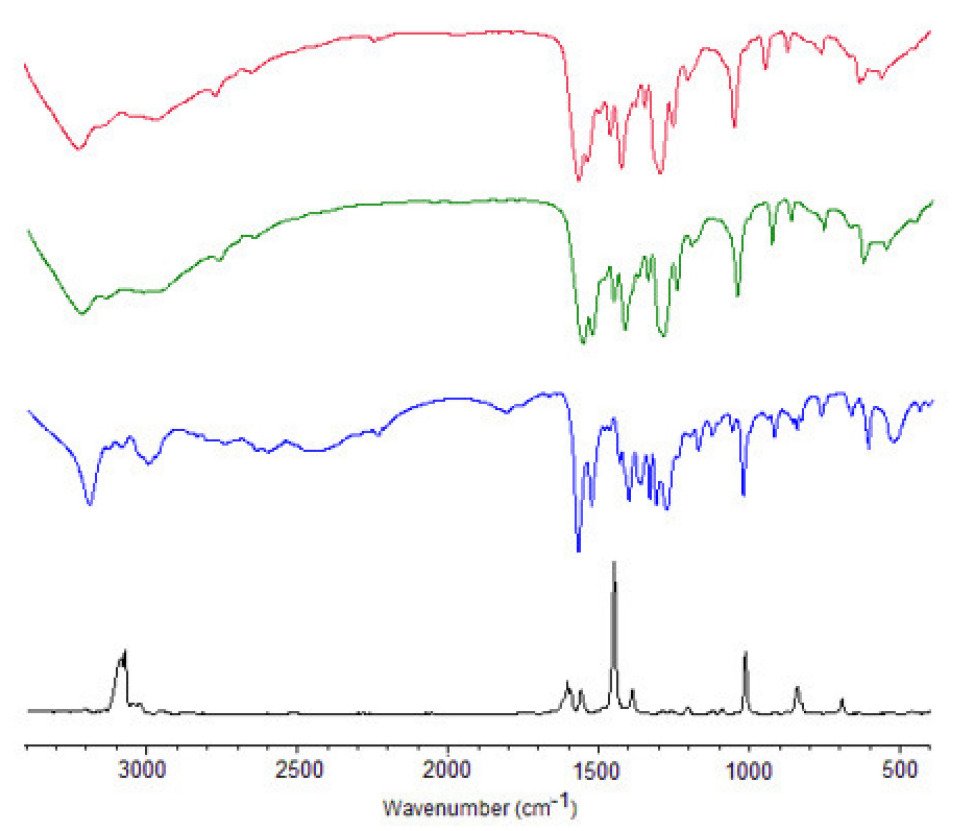

Figure 2. IR spectra of dacarbazine (blue line), cobalt complex (red line), copper complex (green line), and Raman spectra of dacarbazine (black line).

The wavenumbers and intensities of selected bands from the experimental and theoretical IR and Raman spectra of ligand and experimental IR spectra of complexes are gathered in Table 1. The assignment of bands was done on the basis of theoretical wavenumbers obtained at the B3LYP/6-311++G $\mathrm{G}^{* *}$ level as well as literature data [45]. The theoretical wavenumbers were scaled to reproduce adequately the experimental wavenumbers $(f=0.967)$. Some characteristic bands occurred in the experimental spectra of dacarbazine, 
i.e., bands assigned to the stretching vibrations of the carbonyl group $v \mathrm{C}=\mathrm{O}$ at $1609 \mathrm{~cm}^{-1}$ (IR) and $1604 \mathrm{~cm}^{-1}$ (Raman). The theoretical wavenumbers of the $\nu \mathrm{C}=\mathrm{O}$ band were $1691 \mathrm{~cm}^{-1}$ (for the DAC1 conformer) and $1683 \mathrm{~cm}^{-1}$ (in the case of the DAC2 conformer) (Figure 3) (the values scaled by the factor $\mathrm{f}=0.967$ ). In the IR spectra of $\mathrm{Co}$ (II) and $\mathrm{Cu}$ (II) complexes of dacarbazine the $v \mathrm{C}=\mathrm{O}$ band was of similar wavenumbers and reduced intensities compared with the spectra of ligand (i.e., $1605 \mathrm{~cm}^{-1}-\mathrm{Co}$ (II) complex and $1609 \mathrm{~cm}^{-1}-\mathrm{Cu}$ (II) complex). This suggested that the carbonyl group did participate in metal ion coordination. In the spectra of dacarbazine and its metal complexes, the characteristic bands assigned to the vibrations of $\mathrm{NH}_{2}$ (of amide group) occurred. There were bands of the stretching asymmetric vibrations $v_{\mathrm{as}} \mathrm{NH}_{2}$ located at $3383 \mathrm{~cm}^{-1}$ (IR) and $3371 \mathrm{~cm}^{-1}$ (Raman) as well as stretching symmetric vibration $v_{\mathrm{s}} \mathrm{NH}_{2}$ near $3269 \mathrm{~cm}^{-1}$ (IR). In the spectra of complexes, the bands assigned to the stretching vibrations $v_{a s} \mathrm{NH}_{2}$ were significantly shifted whereas bands of $v_{\mathrm{as}} \mathrm{NH}_{2}$ disappeared compared with the appropriate bands in the spectra of ligand. Significant changes were also observed in the case of deforming out-of-plane vibrations of $\mathrm{NH}_{2}$ group $\left(\mathrm{\rho NH}_{2}\right)$, i.e., $1436 \mathrm{~cm}^{-1}$ in the spectrum of ligand, $1440 \mathrm{~cm}^{-1}$ for $\mathrm{Cu}$ and Co complexes as well as $542 \mathrm{~cm}^{-1}$ for ligand and $565 \mathrm{~cm}^{-1}$ for the Co complex and $568 \mathrm{~cm}^{-1}$ for the $\mathrm{Cu}$ complex. The metal complexation affected the location of the band derived from the vibrations of the $\mathrm{C}-\mathrm{NH}_{2}$ group as well. Namely, the band of deforming out-of-plane vibrations $\rho \mathrm{C}-\mathrm{NH}_{2}$ was located at $1476 \mathrm{~cm}^{-1}$ and underwent movement to the $1487 \mathrm{~cm}^{-1}$ and $1488 \mathrm{~cm}^{-1}$ in the cobalt and copper complexes of dacarbazine, respectively. The characteristic changes in the wavenumbers of the bands assigned to the vibrations of $\mathrm{N}=\mathrm{N}-\mathrm{N}$ and $\mathrm{CH}_{3}$ groups were observed.
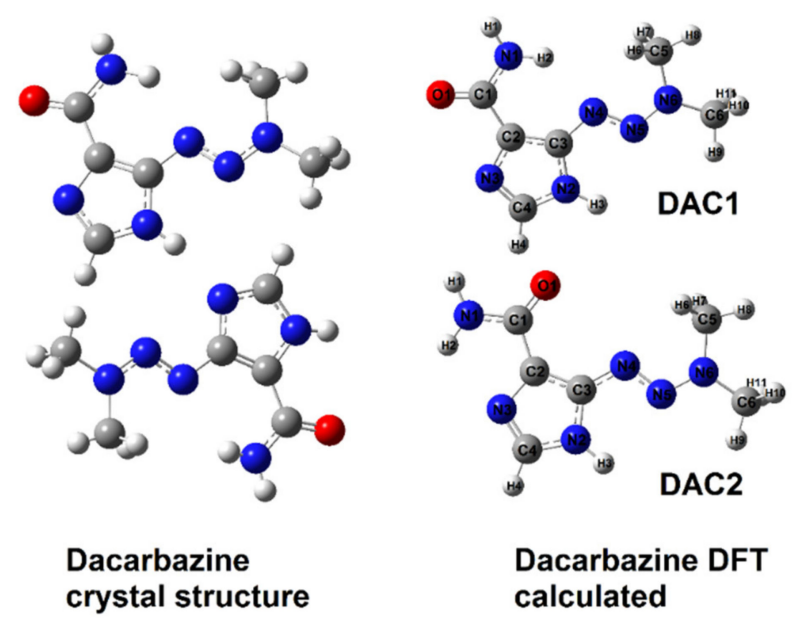

Figure 3. Crystal and theoretical structure (B3LYP/6-311++g(d,p)) of dacarbazine.

The band assigned to the deformations of the triazene group $\alpha$ NNN was located at $630 \mathrm{~cm}^{-1}$ in the spectra of ligand, and then was shifted toward higher wavenumbers in the spectra of complexes ( $649 \mathrm{~cm}^{-1}-\mathrm{Cu}$ complex and $646 \mathrm{~cm}^{-1}-\mathrm{Co}$ complex). The symmetric stretching vibrations of the methyl group $v_{\mathrm{s}} \mathrm{CH}_{3}$, which were present in the spectra of ligand at $3147,2946,2753$, and $2612 \mathrm{~cm}^{-1}$ disappeared in the spectra of metal complexes. Whereas band of asymmetric stretching vibrations of the methyl group $v_{\mathrm{s}} \mathrm{CH}_{3}$ were significantly shifted in the spectra of complexes compared with the spectra of ligand, i.e., $2905 \mathrm{~cm}^{-1}$ in the IR spectra of dacarbazine and $2925 \mathrm{~cm}^{-1}$ and $2923 \mathrm{~cm}^{-1}$ in the IR spectra of $\mathrm{Co}$ and $\mathrm{Cu}$ complexes, respectively. The band of the deforming in-plane vibrations of the methyl group of dacarbazine disappeared or decreased/increased in their wavenumbers in the spectra of $\mathrm{Cu}$ and Co complexes (Table 1). 
Table 1. The wavenumbers from the IR (theoretical and experimental) and Raman spectra of dacarbazine and IR spectra of dacarbazine complexes with cobalt and copper.

\begin{tabular}{|c|c|c|c|c|c|c|c|c|c|c|}
\hline \multirow[b]{2}{*}{ DAC 1} & \multicolumn{4}{|c|}{ Calculated IR (B3LYP 6-311G(d,p) } & \multicolumn{5}{|c|}{ Experimental Spectra $\left(\mathrm{cm}^{-1}\right)$} & \\
\hline & & & DAC 2 & & & DAC & & $\begin{array}{c}\text { Cobalt } \\
\text { Complex }\end{array}$ & $\begin{array}{l}\text { Copper } \\
\text { Complex }\end{array}$ & \\
\hline Unscaled & Scaled $=0.967$ & Intensity & Unscaled & Scaled $=0.967$ & Intensity & IR & Raman & IR & IR & Assignments \\
\hline 3703 & 3581 & 105.50 & 3728 & 3605 & 72.84 & $3383 \mathrm{~s}$ & $3371 \mathrm{w}$ & $3406 \mathrm{~s}$ & $3406 \mathrm{~s}$ & $v_{\text {as }} \mathrm{NH}_{2}$ \\
\hline 3647 & 3527 & 58.23 & 3560 & 3443 & 65.93 & - & - & $3322 \mathrm{~s}$ & - & $v \mathrm{NH}$ \\
\hline 3549 & 3432 & 60.67 & 3585 & 3467 & 53.44 & $3269 \mathrm{~m}$ & - & - & - & $v_{\mathrm{S}} \mathrm{NH}_{2}$ \\
\hline 3238 & 3131 & 2.26 & 3240 & 3133 & 2.09 & $3174 \mathrm{~m}$ & - & $3188 \mathrm{~s}$ & $3186 \mathrm{~s}$ & $v \mathrm{CH}_{\mathrm{ar}}$ \\
\hline 3139 & 3035 & 8.76 & 3139 & 3035 & 5.32 & $2964 \mathrm{~m}$ & - & - & - & $\rho_{\mathrm{s}} \mathrm{CH}$ \\
\hline 3085 & 2983 & 13.51 & 3097 & 2995 & 15.07 & $2905 \mathrm{~m}$ & & $2925 \mathrm{~m}$ & $2923 \mathrm{~m}$ & $v_{\mathrm{as}} \mathrm{CH}_{3}$ \\
\hline 3078 & 2976 & 26.13 & 3074 & 2973 & 28.84 & $2793 \mathrm{~m}$ & - & - & $2796 \mathrm{w}$ & $v_{\text {as }} \mathrm{CH}_{3}$ \\
\hline 3014 & 2915 & 47.62 & 3021 & 2921 & 40.93 & $2753 \mathrm{~m}$ & - & - & - & $v_{\mathrm{s}} \mathrm{CH}_{3}$ \\
\hline 3003 & 2904 & 78.48 & 2997 & 2898 & 94.76 & $2612 \mathrm{~m}$ & - & - & - & $v_{\mathrm{s}} \mathrm{CH}_{3}$ \\
\hline 1749 & 1691 & 494.07 & 1740 & 1683 & 326.18 & 1609 vs & $1604 \mathrm{w}$ & $1605 \mathrm{~s}$ & $1609 \mathrm{~s}$ & $v \mathrm{C}=\mathrm{O}$ \\
\hline- & - & - & - & - & - & 1656 vs & - & 1637 vs & 1639 vs & $v \mathrm{CH}_{3}$ \\
\hline 1620 & 1567 & 141.69 & 1607 & 1554 & 256.98 & - & - & - & - & $\rho \mathrm{C}-\mathrm{NH}_{2}$ \\
\hline- & - & - & - & - & - & $1561 \mathrm{w}$ & 1559 w & $1561 \mathrm{~m}$ & $1566 \mathrm{~m}$ & $\rho_{\mathrm{s}} \mathrm{CH}_{3}$ \\
\hline 1527 & 1477 & 197.90 & 1525 & 1475 & 155.81 & $1476 \mathrm{~s}$ & $1488 \mathrm{vw}$ & 1487 vs & 1488 vs & $\rho C-\mathrm{NH}_{2}$ \\
\hline 1483 & 1434 & 27.90 & 1481 & 1432 & 25.74 & $1436 \mathrm{~m}$ & 1449 vs & $1440 \mathrm{~m}$ & $1440 \mathrm{~m}$ & $\rho \mathrm{NH}_{2}$ \\
\hline 1451 & 1403 & 75.22 & 1453 & 1405 & 32.35 & $1402 \mathrm{~s}$ & - & $1405 \mathrm{~m}$ & $1405 \mathrm{~m}$ & $v C C, v_{\text {ring }}, \rho \mathrm{NH}_{2}$ \\
\hline 1438 & 1391 & 5.80 & 1438 & 1391 & 9.68 & - & - & - & - & $v \mathrm{CC}, \alpha \mathrm{N}-\mathrm{CH}_{2}, \beta \mathrm{NCH}$ \\
\hline 1431 & 1384 & 47.98 & 1430 & 1383 & 74.13 & $1381 \mathrm{~s}$ & $1388 \mathrm{w}$ & - & - & $\beta_{\text {as }} \mathrm{CH}_{3}, \nu_{\text {ring }}$ \\
\hline 1389 & 1343 & 21.23 & 1388 & 1342 & 24.58 & $1344 \mathrm{~s}$ & - & 1352 vs & 1351 vs & $\beta_{\mathrm{s}} \mathrm{CH}_{3}, \nu_{\text {ring }}$ \\
\hline 1363 & 1318 & 114.39 & 1367 & 1322 & 408.84 & $1304 \mathrm{~m}$ & - & $1306 \mathrm{~s}$ & 1307 s & $\beta_{\mathrm{s}} \mathrm{CH}_{3}, \nu_{\text {ring }}$ \\
\hline 1331 & 1287 & 36.74 & 1328 & 1284 & 40.87 & $1270 \mathrm{w}$ & $1289 \mathrm{vw}$ & - & - & $\beta_{\mathrm{s}} \mathrm{CH}_{3}, \gamma_{\text {ring }}, \beta \mathrm{NCH}$ \\
\hline 1270 & 1228 & 2.30 & 1260 & 1218 & 16.53 & $1259 \mathrm{w}$ & $1258 \mathrm{vw}$ & 1253 vs & $1255 \mathrm{~m}$ & $v \mathrm{CN}, \beta \mathrm{CH}$ \\
\hline 1231 & 1190 & 67.15 & 1233 & 1192 & 20.71 & $1231 \mathrm{~m}$ & $1204 \mathrm{vw}$ & - & - & $v_{\text {ring }}, \beta \mathrm{CH}$ \\
\hline 1153 & 1115 & 25.50 & 1152 & 1114 & 39.12 & $1183 \mathrm{w}$ & - & - & - & $\beta C H+v N N$ \\
\hline 1136 & 1099 & 26.51 & 1137 & 1099 & 9.08 & $1072 \mathrm{~s}$ & $1091 \mathrm{vw}$ & $1091 \mathrm{~s}$ & $1091 \mathrm{~s}$ & $v N N, \beta C H$ \\
\hline 1114 & 1077 & 24.06 & 1110 & 1073 & 7.62 & - & - & - & - & $\beta \mathrm{CH}+\beta \mathrm{CNC}$ \\
\hline 1091 & 1055 & 202.22 & 1093 & 1057 & 17.91 & 1049 w & 1012 m & - & - & $\rho \mathrm{CH}_{2}, \beta \mathrm{CH}$ \\
\hline 1084 & 1048 & 12.72 & 1075 & 1040 & 117.70 & $986 \mathrm{w}$ & - & - & - & $\rho \mathrm{C}-\mathrm{NH}_{2}, \beta \mathrm{CNC}$ \\
\hline 1062 & 1027 & 14.22 & 1061 & 1026 & 18.40 & $962 \mathrm{w}$ & - & $969 \mathrm{~m}$ & $980 \mathrm{w}$ & $\rho \mathrm{CH}_{2}, \beta \mathrm{CNC}$ \\
\hline
\end{tabular}


Table 1. Cont.

\begin{tabular}{|c|c|c|c|c|c|c|c|c|c|c|}
\hline \multirow[b]{2}{*}{ DAC 1} & \multicolumn{5}{|c|}{ Calculated IR (B3LYP 6-311G(d,p) } & \multicolumn{4}{|c|}{ Experimental Spectra $\left(\mathrm{cm}^{-1}\right)$} & \\
\hline & & & DAC 2 & & & DAC & & $\begin{array}{l}\text { Cobalt } \\
\text { Complex }\end{array}$ & $\begin{array}{l}\text { Copper } \\
\text { Complex }\end{array}$ & \\
\hline Unscaled & Scaled $=0.967$ & Intensity & Unscaled & Scaled $=0.967$ & Intensity & IR & Raman & IR & IR & Assignments \\
\hline 951 & 920 & 4.32 & 955 & 923 & 15.06 & $904 \mathrm{w}$ & $913 \mathrm{vw}$ & $902 \mathrm{w}$ & $902 \mathrm{w}$ & $\rho \mathrm{CH}_{3}, \beta \mathrm{CH}$ \\
\hline 915 & 885 & 14.86 & 912 & 882 & 16.25 & 896 w & - & - & - & $\rho \mathrm{CH}_{3}, v_{\text {ring }}$ \\
\hline 817 & 790 & 9.74 & 812 & 785 & 5.02 & $882 \mathrm{w}$ & - & - & - & $\Delta$ ring, $v_{\text {ring }}(\mathrm{CN})$ \\
\hline 799 & 773 & 2.21 & 799 & 773 & 2.40 & $868 w$ & $873 \mathrm{vw}$ & - & - & $\rho \mathrm{CH}_{3}, v_{\text {ring }}$ \\
\hline 797 & 771 & 10.95 & 798 & 772 & 14.79 & $796 \mathrm{w}$ & - & - & - & $\beta N C H, \beta N C C$ \\
\hline 672 & 650 & 13.44 & 683 & 660 & 14.27 & $690 \mathrm{w}$ & $691 \mathrm{w}$ & - & - & $\beta \mathrm{NH}, \beta \mathrm{CCO}$ \\
\hline 668 & 646 & 0.82 & 679 & 657 & 0.01 & $653 \mathrm{vw}$ & - & - & - & $\beta(\mathrm{CCN}+\mathrm{NH})$ \\
\hline 632 & 611 & 25.62 & 602 & 582 & 43.51 & $630 \mathrm{~m}$ & - & $646 \mathrm{~m}$ & $649 \mathrm{~m}$ & $\alpha \mathrm{NNN}, \alpha \mathrm{CNC}$ \\
\hline 586 & 567 & 0.50 & 596 & 576 & 0.65 & $542 \mathrm{~m}$ & - & $565 \mathrm{~m}$ & $568 \mathrm{~m}$ & $\rho \mathrm{NH}_{2}, \alpha \mathrm{NNH}, \alpha \mathrm{CCO}$ \\
\hline 552 & 534 & 73.21 & 574 & 555 & 104.33 & $450 \mathrm{w}$ & $445 \mathrm{vw}$ & - & - & ring $_{\mathrm{def}}$ \\
\hline 550 & 532 & 39.82 & 568 & 549 & 10.64 & - & - & - & - & ring def $_{\text {de }}$ \\
\hline 447 & 432 & 10.01 & 449 & 434 & 11.86 & $416 \mathrm{vw}$ & - & - & - & $\alpha \mathrm{C}-\mathrm{NH}_{2}$ \\
\hline
\end{tabular}

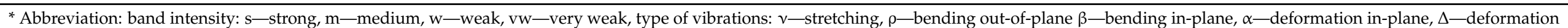

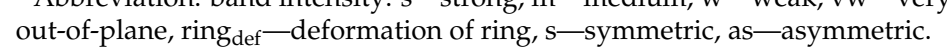


Moreover, the coordination of copper(II) and cobalt(II) by dacarbazine caused changes in the spectra of complexes in the region of bands assigned to the stretching $\left(v_{\text {ring }}\right)$ and deforming $\left(\right.$ ring $_{\text {def }}$ ) vibrations of the ring (compared with the appropriate bands in the spectra of dacarbazine). Namely, $v_{\text {ring }}$ bands located at 1381, 1270,1231 $\mathrm{cm}^{-1}$, and ring def bands near 882 and $450 \mathrm{~cm}^{-1}$ disappeared in the spectra of metal complexes. Whereas $v_{\text {ring }}$ bands situated in the spectra of ligand at 1344 and $1402 \mathrm{~cm}^{-1}$ were slightly shifted to the higher wavenumbers in the spectra of complexes. The band of stretching vibrations of the $\mathrm{CH}$ bond of the aromatic ring of dacarbazine located at $3174 \mathrm{~cm}^{-1}$ was shifted toward higher wavenumbers in the spectra of complexes (i.e., $3188 \mathrm{~cm}^{-1}-\mathrm{Co}$ (II) complex and $1386 \mathrm{~cm}^{-1}-\mathrm{Cu}$ (II) complex). The deforming vibrations of the $\mathrm{CH}$ bond of the ring slightly moved to the higher wavenumbers in the spectra of complexes compared with the spectra of ligand.

The difference between the location of the appropriate bands in the spectra of dacarbazine and copper(II) and cobalt(II) complexes of dacarbazine might be caused by the coordination of metal ions by the oxygen atom of carbonyl group and nitrogen atom of imidazole ring.

\subsection{NMR Spectra}

In the experimental ${ }^{1} \mathrm{HNMR}$ spectra of dacarbazine, four groups signals from protons were observed (Table 2 and Figure S1). The values of the chemical shift for two protons of the amide group have been values 7.41 and $7.29 \mathrm{ppm}$. This signal possessed very low intensity in the spectra of the cobalt complex, and was shifted to 6.20, 5.40, giving extended signals, due to changes in the electronic density in the amide group, due to the attachment of a metal to this group. In the spectra of ligand, the signals at 3.13-3.50 ppm were assigned to the protons of the methyl group.

Table 2. The chemical shifts (ppm) from the ${ }^{1}$ HNMR theoretical (GIAO/B3LYP/6-311++G $\mathrm{G}^{* *}$ ) and experimental spectra of dacarbazine and experimental spectra of cobalt and copper complexes with dacarbazine.

\begin{tabular}{|c|c|c|c|c|c|}
\hline & & \multirow{2}{*}{ DAC 1} & \multirow{2}{*}{ DAC 2} & \multicolumn{2}{|c|}{ Dacarbazine Complexes } \\
\hline & & & & Cobalt & Copper \\
\hline \multirow{2}{*}{ H (amide group) } & Exp. & $7.29,7.41$ & - & $6.20,5.40$ & - \\
\hline & Theoret. & $6.86,4.57$ & $6.87,4.40$ & 6.38 & $8.29,5.42$ \\
\hline \multirow{2}{*}{$\mathrm{H}\left(\mathrm{CH}_{\text {ring }}\right)$} & Exp. & 7.83 & - & 8.04 & - \\
\hline & Theoret. & 7.20 & 6.98 & 8.90 & 7.74 \\
\hline \multirow{2}{*}{$\mathrm{H}\left(\mathrm{NH}_{\text {ring }}\right)$} & Exp. & 11.52 & - & - & - \\
\hline & Theoret. & 8.56 & 8.72 & 9.43 & 8.81 \\
\hline \multirow{3}{*}{$\begin{array}{l}\mathrm{H}\left(\mathrm{CH}_{3} \text {-triazene }\right. \\
\text { group) }\end{array}$} & Exp. & $3.13,3.50$ & - & 3.49 & - \\
\hline & Theoret. & $3.67,3.48,3.36$ & $4.73,4.37,3.91$ & $3.78,3.74,3.71$ & $3.62,3.61,3.61$, \\
\hline & intoret. & $3.19,2.29,2.59$ & $3.88,3.69,3.17$ & $3.44,3.34,3.14$ & $3.24,3.23,3.03$ \\
\hline
\end{tabular}

Complexation of dacarbazine by the cobalt caused insignificant displacement of this signal. On the basis of the value of signals deriving from the aromatic protons (imidazole ring), the effect of metal ions on the electronic charge distribution of ligand might be discussed. The movement of the chemical shifts of aromatic protons toward higher wavenumbers showed an increase in the aromaticity of the ring as well as the stabilization of the aromatic system [20]. In the case of cobalt(II) complexes of dacarbazine, an increase in the value of the chemical shift of protons of $\mathrm{CH}$ bond of the aromatic ring was observed (Figure S1). Proton NMR spectrum for the copper complex could not be recorded. The theoretically calculated chemical shifts in the proton spectrum of the copper complex show similar trends in proton shifts relative to the ligand as in the cobalt complex. Cobalt and copper possess a stabilizing effect on the electronic system of ligand. The same effect was observed on the basis of the IR spectra of $\mathrm{Co}$ and $\mathrm{Cu}$ complexes of dacarbazine (an increase in the values of the wavenumbers and intensities of the aromatic ring). Our long-term 
study on the influence of metals on the electronic system of ligand (aromatic and heteroaromatic system of five- and six-membered carboxylic acids) showed that $3 \mathrm{~d}$ transition metals (including cobalt and copper) stabilize the electronic system of ligands [20-24]. In the spectra of such complexes (a) an increase in the values of signals of the aromatic protons (in ${ }^{1}$ HNMR spectra), and (b) an increase in wavenumbers and intensity of bands assigned to the aromatic system (in the IR spectra) compared with the appropriate signals/bands in the spectra of ligand were observed.

\subsection{Structure, Aromaticity, and NBO Analysis of Dacarbazine and Copper and Cobalt Complexes}

The dacarbazine molecule has a triazene moiety linked to an imidazole ring. IR, NMR studies and literature X-ray data on the structure of dacarbazine complexes [46] showed that metals such as copper and cobalt coordinate the ligand (dacarbazine) through the carbonyl group and the nitrogen atom from the imidazole ring. A similar type of metal-ligand coordination has been observed for 3d-transition metal complexes with imidazole carboxylic acid [38]. On the basis of spectroscopic studies (IR, Raman) and theoretical calculations, it was found that $3 \mathrm{~d}$ metals affect the electronic charge distribution of the aromatic ring of ligand. With the increase in the electronic stability of the ligand, the reactivity of the compound changes, which is important in the case of biologically active ligands. Theoretical structures of dacarbazine complexes with cobalt and copper were calculated. The calculated bond lengths and the values of the selected angles were compared with these ones obtained for experimentally solved structures (X-ray) available in the literature. The geometric indices of aromaticity (HOMA, GEO, EN, and I5) and the electronic charge distribution by the NBO method were also calculated. Figure 3 shows the experimentally determined structure [46] and the calculated two dacarbazine conformers (at B3LYP method). Figure 4 shows the experimental structure of the complex of copper with dacarbazine (A) [47] and the theoretically modeled structures of the complexes with copper (B) and cobalt (C).

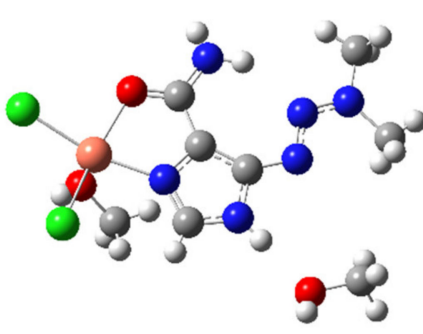

A

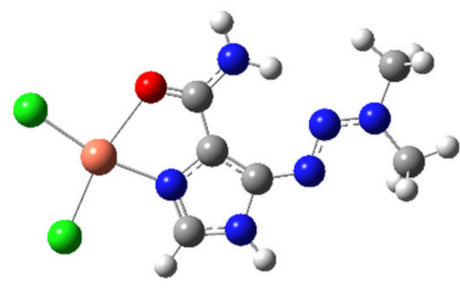

B

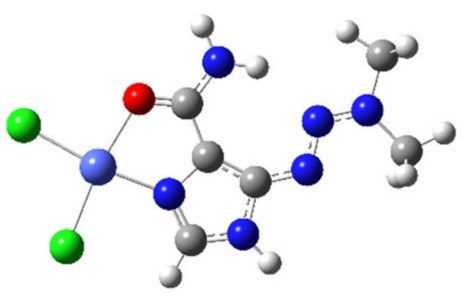

C

Figure 4. Crystal (A), theoretical structure (B3LYP/6-311++g(d,p)) of cobalt $($ B) and copper (C) complex with dacarbazine.

Both theoretically modeled dacarbazine conformational structures have similar energy values. According to the calculated geometric aromaticity indices, the imidazole ring of the DAC1 structure is more stable than the DAC2 structure (Table 3). The system is stabilized by an intramolecular hydrogen bond between the hydrogen atom of the amino group and the nitrogen atom of the triazene group. The length of this bond is $2.154 \AA$. In the DAC2 structure, the amide moiety is rotated $180^{\circ}$ along the $\mathrm{C} 1-\mathrm{C} 2$ carbons as compared to the DAC1 structure. The aromatic system of imidazole in this structure is less stable, as evidenced by the values of the aromaticity indices. The structure of the DAC1 monomer is the same as that of experimentally determined dacarbazine. In the structure determined by the X-ray diffraction method [42], there is an intramolecular hydrogen bond that stabilizes the aromatic system between the hydrogen atom of the amino group and the triazene nitrogen atom with a length of $2.294 \AA$, and an intermolecular hydrogen bond with a length of $1.945 \AA$. The values of geometric aromaticity indices calculated for the experimental structure and the theoretically modeled DAC1 are at a similar level (Table 3). The differences in the lengths of the corresponding bonds in the experimentally determined 
dacarbazine structure and the theoretically modeled DAC1 monomer range from 0.001 to $0.026 \AA$.

Table 3. Geometrical aromaticity parameters and selected bond lengths and angle values obtained for dacarbazine and copper(II) and cobalt(II) complexes of dacarbazine.

\begin{tabular}{|c|c|c|c|c|c|c|}
\hline & \multicolumn{3}{|c|}{ Dacarbazine } & \multicolumn{2}{|c|}{ Copper Complex } & \multirow{2}{*}{$\begin{array}{l}\text { Cobalt Complex } \\
\text { Calc }\end{array}$} \\
\hline & $\operatorname{Exp}[46]$ & DAC1 & DAC2 & $\operatorname{Exp}[47]$ & Calc & \\
\hline Energy & - & -638.54 & -638.54 & - & -3199.60 & -2941.88 \\
\hline Dipole m & - & 10.7498 & 5.5647 & - & 21.8411 & 22.5754 \\
\hline \multicolumn{7}{|c|}{ Aromaticity indices } \\
\hline HOMA & 0.905 & 0.893 & 0.880 & 0.925 & 0.897 & 0.890 \\
\hline GEO & 0.060 & 0.069 & 0.079 & 0.057 & 0.065 & 0.067 \\
\hline $\mathrm{EN}$ & 0.035 & 0.039 & 0.041 & 0.017 & 0.039 & 0.043 \\
\hline I5 & 67.97 & 67.39 & 65.35 & 70.44 & 68.42 & 67.68 \\
\hline \multicolumn{7}{|c|}{ Bond lengths $[\mathrm{A}]$} \\
\hline C1-O1 & 1.230 & 1.218 & 1.222 & 1.362 & 1.236 & 1.247 \\
\hline C1-N1 & 1.338 & 1.370 & 1.366 & 1.309 & 1.345 & 1.342 \\
\hline $\mathrm{C} 1-\mathrm{C} 2$ & 1.470 & 1.492 & 1.484 & 1.460 & 1.477 & 1.465 \\
\hline $\mathrm{C} 2-\mathrm{C} 3$ & 1.379 & 1.392 & 1.388 & 1.387 & 1.393 & 1.392 \\
\hline C3-N2 & 1.375 & 1.377 & 1.381 & 1.370 & 1.383 & 1.381 \\
\hline $\mathrm{N} 2-\mathrm{C} 4$ & 1.352 & 1.370 & 1.367 & 1.345 & 1.356 & 1.359 \\
\hline C4-N3 & 1.333 & 1.307 & 1.309 & 1.311 & 1.311 & 1.312 \\
\hline N3-C2 & 1.387 & 1.376 & 1.383 & 1.379 & 1.379 & 1.384 \\
\hline C3-N4 & 1.383 & 1.384 & 1.380 & 1.387 & 1.382 & 1.380 \\
\hline N4-N5 & 1.285 & 1.270 & 1.279 & 1.286 & 1.273 & 1.274 \\
\hline N5-N6 & 1.304 & 1.325 & 1.326 & 1.299 & 1.314 & 1.313 \\
\hline N6-C5 & 1.451 & 1.456 & 1.458 & 1.450 & 1.455 & 1.455 \\
\hline N6-C6 & 1.449 & 1.453 & 1.451 & 1.450 & 1.458 & 1.458 \\
\hline \multicolumn{7}{|l|}{ Angles $\left(^{\circ}\right)$} \\
\hline N2-C3-N4 & 127.50 & 125.36 & 125.07 & 116.37 & 115.48 & 116.15 \\
\hline C3-N4-N5 & 112.80 & 113.71 & 113.23 & 112.17 & 115.88 & 115.46 \\
\hline N4-N5-N6 & 113.42 & 115.20 & 114.26 & 114.66 & 114.71 & 114.64 \\
\hline N5-N6-C6 & 116.55 & 115.90 & 116.01 & 122.46 & 121.71 & 121.70 \\
\hline C5-N6-C6 & 120.96 & 120.43 & 120.46 & 120.31 & 120.82 & 120.76 \\
\hline C1-C2-N3 & 120.18 & 120.93 & 121.18 & 112.88 & 113.31 & 112.19 \\
\hline O1-C1-N1 & 123.28 & 122.53 & 123.17 & 121.95 & 122.79 & 122.19 \\
\hline
\end{tabular}

The complexation of dacarbazine with $3 \mathrm{~d}$ transition metals (copper and cobalt) influences the stability of the ligand's electronic system, which is observed by changing the aromaticity of the system expressed in the values of aromaticity indices, changes in the distribution of electronic charge, and changes in the bond lengths in the studied systems. The comparison of the structure of the dacarbazine complex with copper [47] to dacarbazine [46] shows that the aromatic system of the imidazole ring is stabilized by complexation (Table 3). It was observed both when comparing the ligand structure to the complex for the experimental and theoretically modeled structures (the effect of the metal is more noticeable when comparing the experimental structures than the theoretically modeled ones). Under the influence of copper, there is a significant change in the length of the imidazole ring bonds, which results in an increase in the HOMA and I5 indices. Complexation of metals by ligand slightly changes the bond length of the triazene moiety (Table 3). The complexation of cobalt with dacarbazine influences the change of aromaticity of the imidazole ligand ring to a lesser extent than complexation of copper (when comparing theoretical structures). A slight increase in the value of the I5 index and a slight decrease in the value of the HOMA index were observed. The theoretical structures of copper and cobalt complexes have similar bond lengths and angles.

It was observed that the complexation of dacarbazine with copper and cobalt slightly changed the bond length of the N4-N5-N6 triazene moiety and the length of the N6-C5 and 
N6-C6 bonds (nitrogen N6 with methyl groups). The analysis of the NBO electronic charge distribution (Table 4) showed that the values of the electronic charges on the nitrogen atoms of the triazene group and the carbons of the methyl groups are similar in the complexes and the ligand.

Table 4. NBO atomic charges calculated for dacarbazine and copper(II) and cobalt(II) complexes of dacarbazine.

\begin{tabular}{ccccc}
\hline & DAC1 & DAC2 & Copper Complex & Cobalt Complex \\
\hline O1 & -0.605 & -0.805 & -0.607 & -0.582 \\
N1 & -0.820 & -0.627 & -0.775 & -0.764 \\
C1 & 0.635 & 0.635 & 0.647 & 0.648 \\
C2 & 0.021 & 0.013 & 0.008 & -0.002 \\
C3 & 0.283 & 0.307 & 0.314 & 0.321 \\
N2 & -0.555 & -0.552 & -0.514 & -0.513 \\
C4 & 0.219 & 0.220 & 0.279 & 0.276 \\
N3 & -0.444 & -0.509 & -0.518 & -0.470 \\
qring & -0.476 & -0.521 & -0.431 & -0.388 \\
N4 & -0.346 & -0.296 & -0.343 & -0.343 \\
N5 & -0.034 & -0.047 & -0.032 & -0.031 \\
N6 & -0.248 & -0.246 & -0.215 & 0.213 \\
C5 & -0.390 & -0.392 & -0.390 & -0.390 \\
C6 & -0.349 & -0.349 & -0.349 & -0.349 \\
\hline
\end{tabular}

On the other hand, the influence of metals on the distribution of electronic charge on the imidazole ring of dacarbazine was observed. The electronic density around the carbon atom labeled C2 and the nitrogen atom N3 increased in copper and cobalt complexes compared to the ligand, while around the C3, C4, and N2 atoms the electronic density decreased (Table 4). The effect of copper on the electronic charge distribution in the imidazole ring of the ligand is greater than that of cobalt. The total electronic density of the C-ring of the copper complex is greater than that of the cobalt complex. Studies of 4-imidazole carboxylic acid complexes with 3d-transition metals (including copper and cobalt) also showed that copper and cobalt had a stabilizing effect on the aromatic system of the imidazole ring [48].

\subsection{HOMO and LUMO Orbitals}

The energy values of the HOMO and LUMO orbitals for dacarbazine as well as copper and cobalt complexes were calculated. The shapes of the orbitals are shown in Figures 5 and 6, while in Table 5 the values of the energy of the orbitals and other electronic parameters are gathered. The highest-occupied molecular orbital (HOMO) and the lowest unoccupied molecular orbital (LUMO) play an important role in predicting charge transfer in the molecule, chemical reactivity, bioactivity, and compound stability [46]. The shapes of the LUMO and HOMO molecular orbitals of the dacarbazine complexes with copper and cobalt are shown in Figure 6. The energy values of the HOMO and LUMO orbitals and the value of the energy difference between the HOMO-LUMO levels for the studied compounds are presented in Table 5. The value of the HOMO-LUMO energy difference (Energy gap) for the copper complex is $0.3761 \mathrm{eV}$, and for the cobalt complex it is $1.5894 \mathrm{eV}$ and the values are lower than those obtained for dacarbazine (3.057 eV for DAC1). This indicates a decrease in kinetic stability and an increase in the reactivity of the complexes toward the ligand. Other general reactivity descriptors $[49,50]$ such as ionization potential $(\mathrm{I})$, electron affinity $(\mathrm{A})$, electronegativity $(\chi)$, chemical hardness $(\eta)$, softness (e), and electrophilicity index $(\omega)$ calculated on the basis of the energy of HOMO and LUMO are summarized in Table 5. The data show that the chemical hardness of the complexes is lower than that of the ligand. The electrophilicity index $(\omega)$ provides information not only about the reactivity but also about the toxicity of the molecule. This indicator is related to the stabilization of energy when the system acquires an additional electrostatic charge 
from the environment and quantifies the global electrophilic force of the molecule [51]. The electrophilicity index for the copper complex is much higher than that of the free ligand (four times higher), while for the cobalt complex it is twice as high as obtained for the ligand.

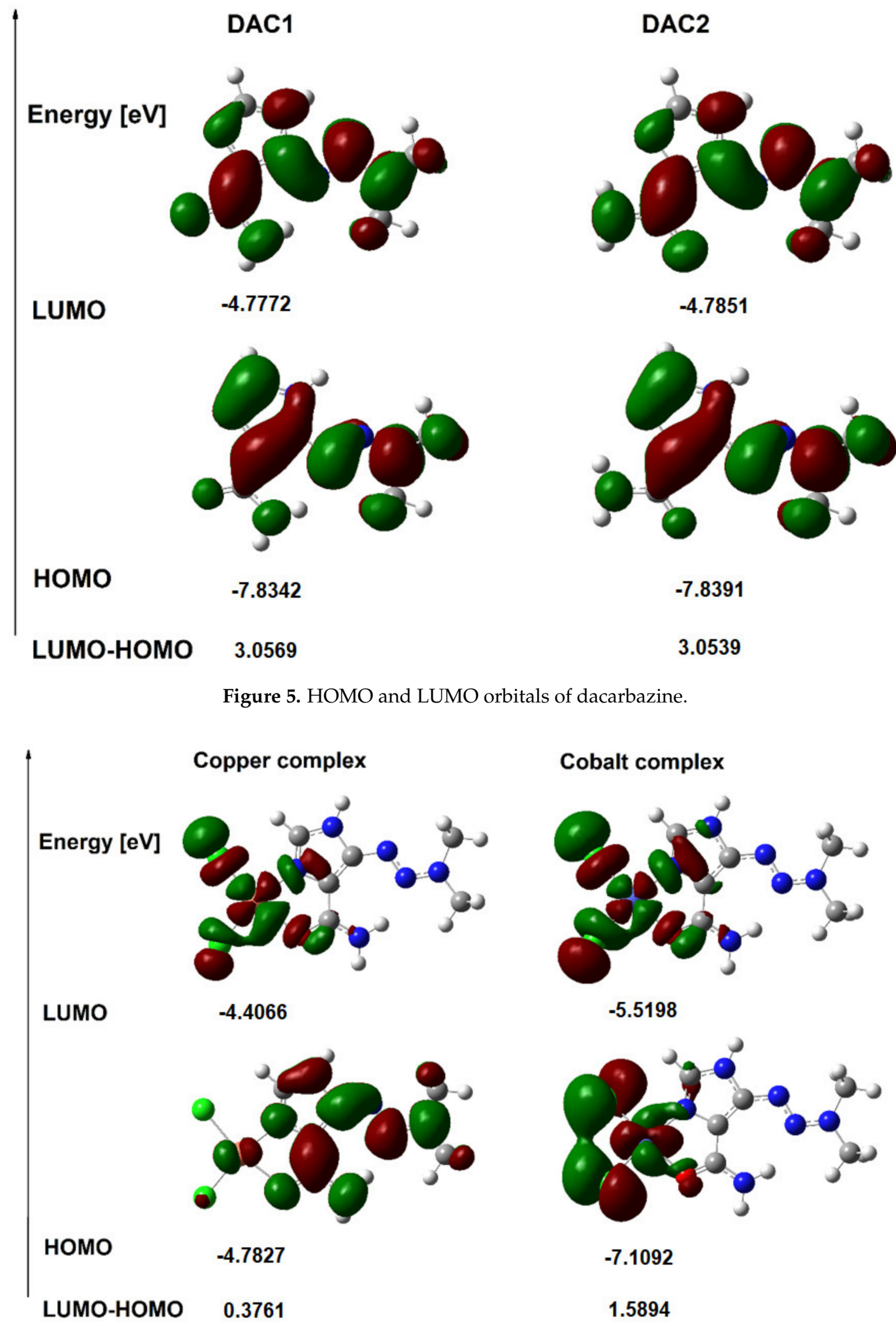

Figure 6. HOMO and LUMO orbitals of copper and cobalt complexes with dacarbazine. 
Table 5. The values of energy of HOMO and LUMO orbitals and other electronic parameters calculated for dacarbazine and copper(II) and cobalt(II) complexes of dacarbazine.

\begin{tabular}{lcccc}
\hline & DAC1 & DAC2 & Copper Complex & Cobalt Complex \\
\hline HOMO & -7.8342 & -7.8391 & -4.7827 & -7.1092 \\
LUMO & -4.7772 & -4.7851 & -4.4066 & -5.5198 \\
Energy gap & 3.057 & 3.054 & 0.3761 & 1.5894 \\
$\begin{array}{l}\text { Ionization } \\
\text { potential }\end{array}$ & 7.8342 & 7.8391 & 4.7827 & 7.1092 \\
$\begin{array}{l}\text { Electron affinity } \\
\text { Electronegativity }\end{array}$ & 4.7772 & 4.7851 & 4.4066 & 5.5198 \\
$\begin{array}{l}\text { Chemical } \\
\text { potential }\end{array}$ & 6.3057 & 6.3121 & 4.59465 & 6.3145 \\
$\begin{array}{l}\text { Chemical } \\
\text { hardness }\end{array}$ & -6.3057 & -6.3121 & -4.59465 & -6.3145 \\
$\begin{array}{l}\text { Chemical } \\
\text { softness }\end{array}$ & 1.5285 & 1.527 & 0.18805 & 0.7947 \\
$\begin{array}{l}\text { Electrophilicity } \\
\text { index }\end{array}$ & 0.327118 & 0.327439 & 2.658867 & 0.629168 \\
\hline
\end{tabular}

\subsection{Docking Studies}

Comparing the average number of hydrogen bonds formed with the B-DNA structure, it was observed that the number of H-Bonds does not change significantly in the case of decarbazine metal complexes compared to ligands.

The obtained results indicate that the significant decrease $(\sim 4 \mathrm{kcal} / \mathrm{M})$ in the free energy of binding the complexes with B-DNA is not due to formed hydrogen bonds (Figure 7). We conclude that formation of the complex causes favorable changes to occur in the distribution of the electronic charge. These changes in the electron density distribution affect the affinity to biological macromolecules like DNA. The tested compounds had an entropy value of $S=13.75 \mathrm{kcal} / \mathrm{mol}$ and an internal energy with values Dac1 $(-4.37 \mathrm{kcal} / \mathrm{mol})$, Dac2 $(-4.26 \mathrm{kcal} / \mathrm{mol}), \mathrm{Cu}-\mathrm{DAC}(-8.13 \mathrm{kcal} / \mathrm{mol})$, and Co-DAC $(-8.19 \mathrm{kcal} / \mathrm{mol})$, respectively (Table 6). The most energetically advantageous complexes with DNA formed two hydrogen bonds with thymine (Figure 8). In the case of constant inhibition, the value for metal complexes decreased by more than 1000-fold, and the free-binding energy decreased by about $4 \mathrm{kcal} / \mathrm{mol}$.

Table 6. Molecular docking analysis results.

\begin{tabular}{|c|c|c|c|c|c|c|c|}
\hline & $\begin{array}{l}\text { Free Energy } \\
\text { of Binding } \\
(\mathrm{kcal} / \mathrm{mol})\end{array}$ & $\begin{array}{c}\text { Inhibition } \\
\text { Constant } \\
(\mu \mathrm{M})\end{array}$ & $\begin{array}{c}\text { Intermolecular } \\
\text { Energy }\end{array}$ & $\begin{array}{c}\text { Torsional } \\
\text { Energy }\end{array}$ & $\begin{array}{l}\text { Unbound } \\
\text { Extended } \\
\text { Energy }\end{array}$ & $\begin{array}{c}\text { Interacting Residues } \\
\text { (H-Bonds) and } \\
\text { Distance }[\AA ̊ \AA\end{array}$ & $\begin{array}{l}\text { Reference } \\
\text { RMSD }\end{array}$ \\
\hline DAC 1 & -5.17 & 163 & -5.99 & 0.82 & -0.38 & $\begin{array}{l}\text { N1-THY B:19 (1.92) } \\
\text { N2-THY A:7 (2.11) }\end{array}$ & 25.45 \\
\hline DAC 2 & -5.13 & 173.91 & -5.95 & 0.82 & -0.37 & $\begin{array}{l}\text { N1-THY B:19 (1.96) } \\
\text { N2:THY A:7 (2.11) }\end{array}$ & 25.43 \\
\hline Cu-DAC & -9.31 & 0.15106 & -10.40 & +1.10 & -0.63 & $\begin{array}{l}\text { N1-THY:A8 (2.19) } \\
\text { N2-THY A:7 (1.86) }\end{array}$ & 25.26 \\
\hline Co-DAC & -9.33 & 0.14391 & -10.43 & +1.10 & -0.56 & $\begin{array}{l}\text { N2-THY A:7 (1.86) } \\
\text { N1-THY B:19 (1.87) }\end{array}$ & 26.06 \\
\hline
\end{tabular}




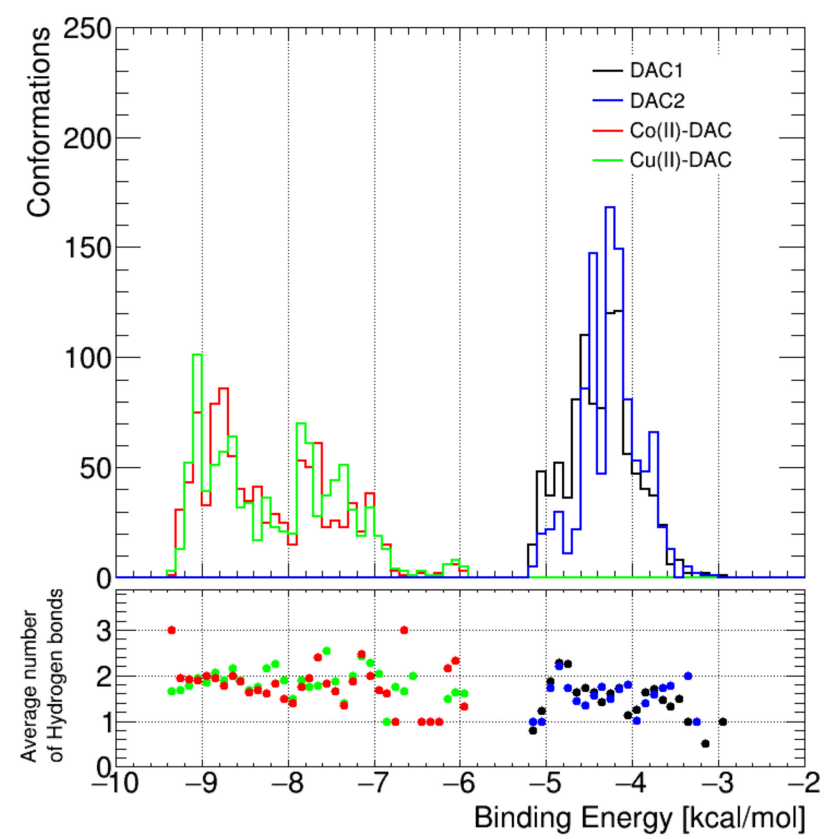

Figure 7. (Upper) Representation of the number of conformations formed by both ligand conformers (DAC1, DAC2) and metal complexes Co(II)-DAC and Cu(II)-DAC. (Lower) Average number of hydrogen bonds formed in complexes and ligands and free binding energy.

In Ahmad and Ahmad's studies, the binding constant $(\mathrm{Kb})$ was $7.89 \times 10^{4}$ experimental isothermal titration calorimetry of ct-DNA-DAC, and $\mathrm{Kb}=6.99 \times 10^{4}$ in docking studies for B-DNA-DAC [52]. Dacarbazine-ctDNA binding energy obtained from ITC experiments was $-5.49 \mathrm{kcal} / \mathrm{mol}$ and it is comparable with minimized free energy of DAC-DNA obtained in docking studies $(-5.35 \mathrm{kcal} / \mathrm{mol})$. The most favorable interactions were found in the A-T residue of the minor DNA groove and hydrogen bonding and van der Waals interactions likely play a major role in these interactions. Previous research described by Wang et al. [53] obtained by atomic force microscopy and nanostructural image of DAC-DNA complexes indicate interaction at some specific site of the DNA sequence without intercalation. Additionally, DAC shows poor binding affinity to ssDNA [53]. Based on cyclic voltammetry, differential pulse voltammetry studies, and using spectroscopic methods performed by Radi et al., it has been concluded that decarbazine binds to double-stranded DNA by the combined effect of intercalation and electrostatic interactions [54].

Temerk and Ibrahim [19] describe that both DAC and DAC-Cu(II) complexes intercalate with base stacking of dsDNA, independent of ionic strength. In contrast, the interaction of a DAC with ssDNA, which is negatively charged, is electrostatic attractions. However, in the presence of $\mathrm{Cu}(\mathrm{II})$, these interactions are much stronger. Values of standard Gibbs free energy $(-\Delta G$ o $)$ in $278 \mathrm{~K}$ for DAC-ssDNA is $28.74 \mathrm{~kJ} / \mathrm{M}(6.87 \mathrm{kcal} / \mathrm{M})$ and for DAC-Cu(II)ssDNA is $29.98 \mathrm{~kJ} / \mathrm{M}(7.17 \mathrm{kcal} / \mathrm{M})$ with enthalpy $\Delta H \circ=21.98 \mathrm{~kJ} / \mathrm{M}$ and $22.29 \mathrm{~kJ} / \mathrm{M}$, respectively. For comparison $-\Delta G$ o for DAC-dsDNA is $25.75 \mathrm{~kJ} / \mathrm{M}$ and $27.55 \mathrm{~kJ} / \mathrm{mol}$ for DAC-Cu-dsDNA [19].

The presented results indicate the formation of beneficial interactions and changes in the distribution of the electronic charge in decarbazine complexes with copper and cobalt, which in turn may enhance the interaction with macromolecules such as DNA. 


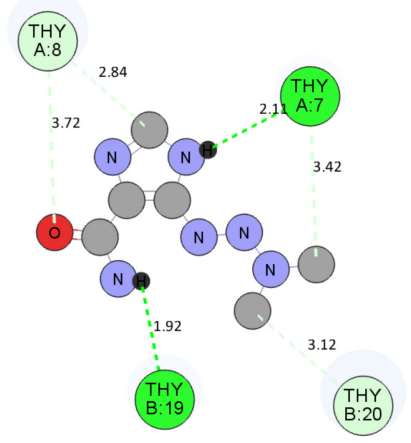

DAC1

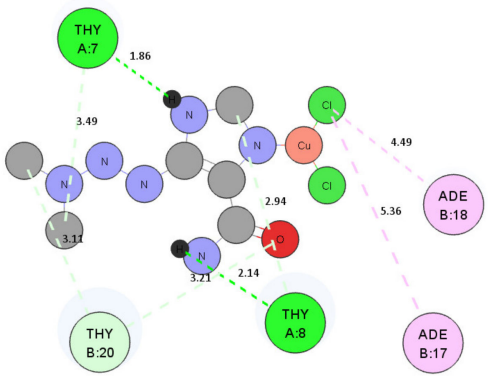

\section{Cu-DAC}

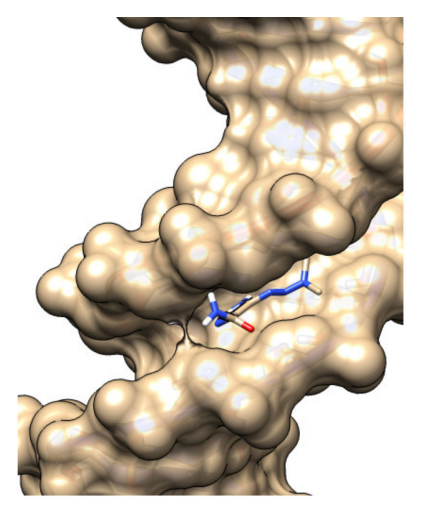

DAC1

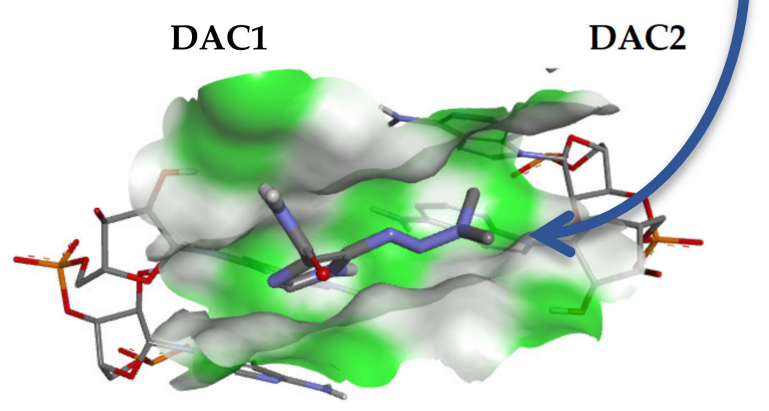

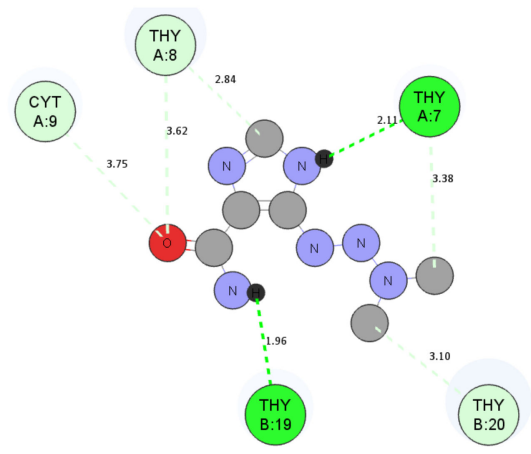

DAC2

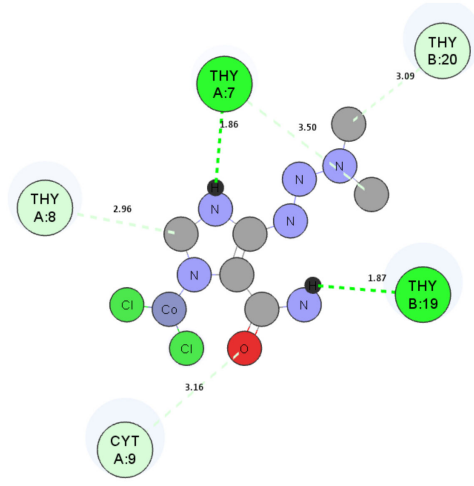

Co-DAC

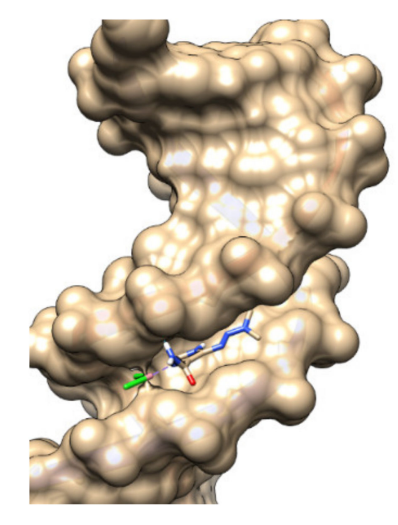

Co-DAC

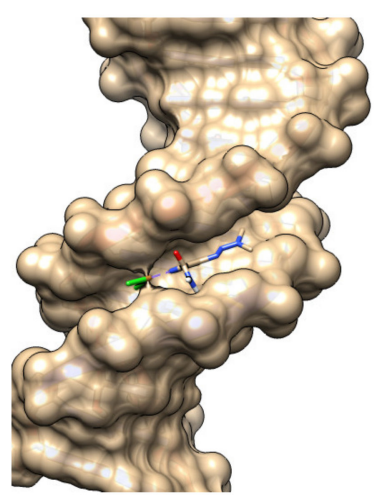

Cu-DAC

Figure 8. Best docking poses of decarbazine and complexes with B-DNA structure (Upper) in 2D with hydrogen bonds (green), Van der Waals (light green), and Pi-Alkyl (pink) interactions. (Lower) 3D visualization of location in the minor groove of DNA. 


\subsection{Thermogravimetric Study}

Thermogravimetric curves of dacarbazine and its metal complexes with copper(II) and cobalt(II) are shown in Figure 9. Dacarbazine underwent immediate decomposition above $205^{\circ} \mathrm{C}$. Rapid mass loss observed on the TG curve was accompanied by a narrow signal on the DTG curve. In the first stage of thermal decomposition of dacarbazine (in the range of $205-210{ }^{\circ} \mathrm{C}$ ), a $50 \%$ loss in weight occurred. The mid weight loss was due to degradation of the triazene group and thermal dissociation of the amide group. The second stage of thermal decomposition of decarbazine was less rapid (above $201{ }^{\circ} \mathrm{C}$ ) - the imidazole ring and $\mathrm{C}=\mathrm{O}$ group totally decomposed, and the total mass loss was at $675{ }^{\circ} \mathrm{C}$ (Table 7).

A

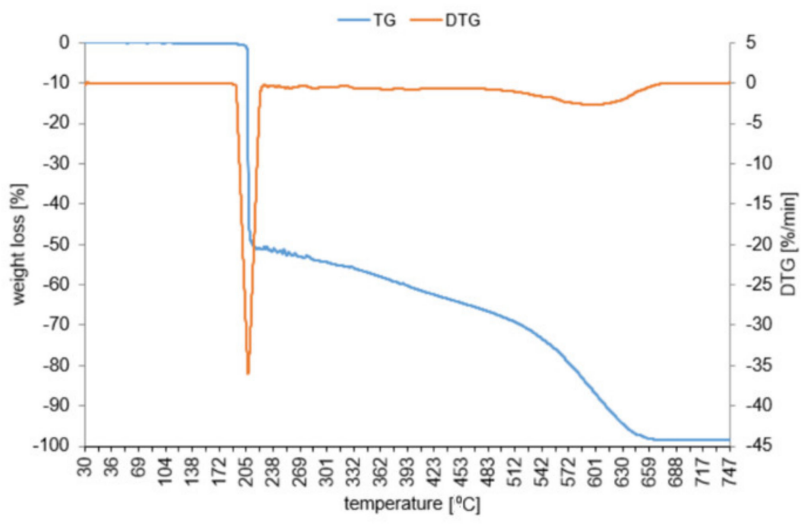

B

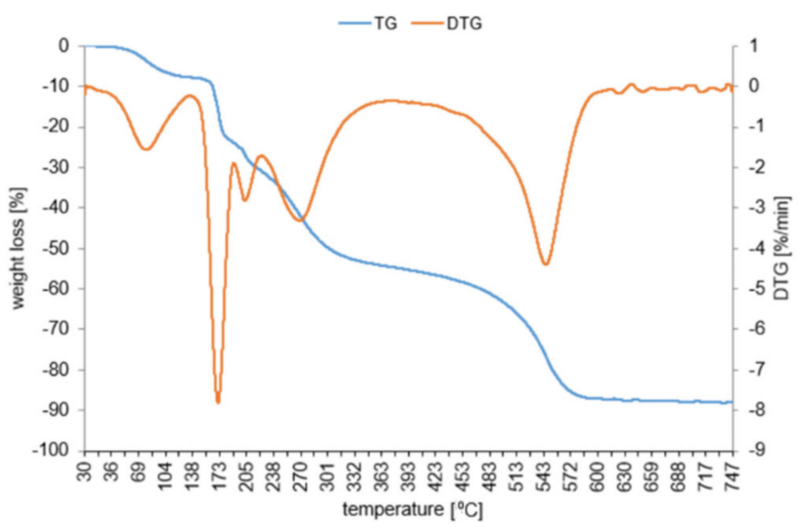

C

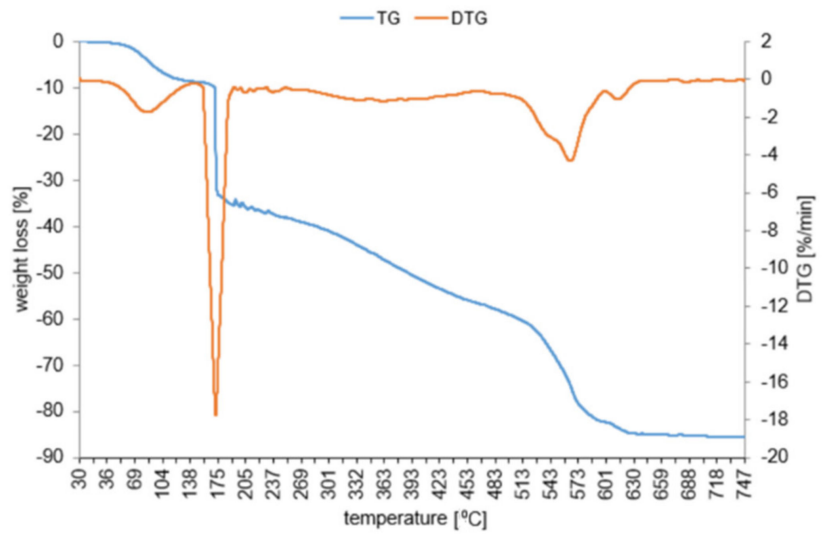

Figure 9. TG/DTG curves of dacarbazine (A), cobalt (B), and copper (C) complexes. 
Table 7. The results of thermal decomposition of dacarbazine and their complexes with cobalt and copper.

\begin{tabular}{|c|c|c|c|c|}
\hline \multirow{2}{*}{ Compound } & \multirow{2}{*}{$\begin{array}{l}\text { Range of } \\
\text { Decomposition }\end{array}$} & \multicolumn{2}{|c|}{ Weight Loss (\%) } & \multirow{2}{*}{$\begin{array}{l}\text { Products of } \\
\text { Decomposition }\end{array}$} \\
\hline & & Calcd. & Found & \\
\hline \multirow{2}{*}{ Dacarbazine } & $205-210$ & 47.70 & 48.50 & Imidazole $+C^{*}$ \\
\hline & $210-660$ & 100 & 100 & - \\
\hline \multirow[t]{2}{*}{$\mathrm{CoCl}_{2}(\mathrm{Dac})_{2} \cdot 75 \mathrm{CH}_{3} \mathrm{OH}$} & $60-120$ & 10.19 & 10.34 & $\mathrm{CoCl}_{2}(\mathrm{Dac})_{2}$ \\
\hline & $175-630$ & 86.38 & 85.61 & $\mathrm{CoO}$ \\
\hline \multirow{2}{*}{$\mathrm{CuCl}_{2}(\mathrm{Dac})_{2} \cdot 1.5 \mathrm{CH}_{3} \mathrm{OH}$} & $60-110$ & 8.78 & 8.39 & $\mathrm{CuCl}_{2}(\mathrm{Dac})_{2}$ \\
\hline & $160-580$ & 85.40 & 87.16 & $\mathrm{CuO}$ \\
\hline
\end{tabular}

$\mathrm{C}^{*}$ - carbon residue.

In the first stage of thermal decomposition of copper(II) and cobalt(II) complexes of dacarbazine the process of methanol desolvation occurred. The cobalt complex totally lost methanol $(1.75 \mathrm{~mole}$ of $\mathrm{CH} 3 \mathrm{OH})$ in the range of $60-120^{\circ} \mathrm{C}$, and the copper complex (1.5 mole of $\mathrm{CH} 3 \mathrm{OH})$ in the range of $60-110{ }^{\circ} \mathrm{C}$. The thermal decomposition of cobalt compound started at $175^{\circ} \mathrm{C}$ (at a much lower temperature than decarbazine). The first stage of decomposition was as rapid as it was in the case of ligand (with a $33 \%$ loss in weight). The second stage of decomposition ran gently until achievement of $540{ }^{\circ} \mathrm{C}$, and then the rapid mass loss occurred. The TG curve possessed a similar shape as the TG curve of decarbazine. At $630^{\circ} \mathrm{C}$ the cobalt complex totally decomposed to CoO.

At the beginning of the thermal decomposition of copper(II) complex of dacarbazine the methanol desolvation occurred. Next the thermal decomposition of the complex started at about $160{ }^{\circ} \mathrm{C}$ (a slightly lower temperature than in the case of dacarbazine). During the thermal decomposition of copper complex, no stable intermediate products were observed (similarly as in the case of the cobalt complex). Above $580^{\circ} \mathrm{C}$ the final product of decomposition $\mathrm{CuO}$ occurred. Comparing the curves of thermal decomposition of studied compounds it appeared that complexes of dacarbazine were less stable than ligand alone. The thermal decomposition of cobalt and copper complexes started at temperatures 35 and 50 degrees lower than ligand, respectively. The cobalt complex of dacarbazine was more thermal stable than the copper complex.

\section{Conclusions}

The spectroscopic IR and NMR studies revealed that dacarbazine coordinates metal cations (cobalt(II) and copper(II)) through the oxygen atom of carbonyl group and nitrogen atoms from the imidazole ring. It was stated on the basis of significant shifts of bands assigned to the vibrations of the aforementioned groups from the infrared spectra and chemical shifts of protons from the ${ }^{1} \mathrm{HNMR}$ spectra (changes in the electronic charge density under the influence of complexation). The thermal analysis showed that cobalt(II) and copper(II) complexes of dacarbazine were less stable than ligand. The cobalt complex of dacarbazine was more thermal stable than the copper complex.

Based on the literature data (X-ray diffraction) and spectroscopic data, the theoretical structures of the complexes were modeled. Experimentally determined and theoretically calculated structures were compared. For the modeled structures, the distribution of electronic charge, aromaticity, and energies of the HOMO and LUMO orbitals were calculated. This allowed the assessment of the effect of complexation with copper and cobalt on the stabilization of the aromatic system and the reactivity of the investigated complexes. Complexation with copper and cobalt changes the electronic charge distribution of dacarbazine. The aromatic system of dacarbazine is stabilized (aromaticity indices increase) due to metal complexation. The values of the calculated energy of the HOMO and LUMO orbitals indicate an increase in the reactivity of the dacarbazine molecule after complexation. This has a significant impact on the biological activity of these substances. The electron charge distribution of a ligand provides information about the stability of a given compound as well as its reactivity and biological activity. By complexing ligands of high biological 
importance with metals, we influence the electronic stability of a given ligand and, at the same time, we can influence its biological activity. Additionally, by examining the thermal properties of given chemical compounds, we can potentially check their susceptibility to thermal utilization and test the decomposition products.

Supplementary Materials: The following are available online at https://www.mdpi.com/article/10 $.3390 / \mathrm{ma14123274/s1}$, Figure S1. ${ }^{1}$ HNMR spectra for dacarbazine and dacarbazine complex with cobalt (II).

Author Contributions: Conceptualization, G.Ś., M.K., and R.Ł., methodology, G.Ś. and M.K., validation, W.L. and R.Ł.; formal analysis, A.O.A., M.M., M.K., G.S., and M.S., investigation, W.L. and R.Ł.; writing—original draft preparation, G.Ś., M.K., R.Ś., A.G., and M.M., visualization, G.Ś., A.G., and A.O.A.; supervision, G.Ś.; project administration, W.L. All authors have read and agreed to the published version of the manuscript.

Funding: Studies have been carried out in the framework of the work no. WZ/WB-IIS/5/2020 in Bialystok University of Technology and financed from the funds for Science, Ministry of Science and Higher Education of Poland.

Institutional Review Board Statement: Not applicable.

Informed Consent Statement: Not applicable.

Data Availability Statement: The data presented in this study are available on request from the corresponding author.

Conflicts of Interest: No potential conflict of interest are reported by the authors.

\section{References}

1. Serrone, L.; Zeuli, M.; Sega, F.M.; Cognetti, F. Dacarbazine-based chemotherapy for metastatic melanoma: Thirty-year experience overview. J. Exp. Clin. Cancer Res. 2000, 19, 21-34.

2. Reid, J.M.; Kuffel, M.J.; Miller, J.K.; Rios, R.; Ammes, M.M. Metabolic activation of dacarbazine by human cytochromes p450: The role of CYP1A1, CYP1A2e CYP2E1. Clin. Cancer Res. 1999, 5, 2192-2197.

3. Nussbaumera, S.; Bonnabry, P.; Veuthey, J.L.; Fleury-Souverain, S. Analysis of anticancer drugs: A review. Talanta 2011, 85, 2265-2289. [CrossRef] [PubMed]

4. Moody, C.L.; Wheelhouse, R.T. The Medicinal Chemistry of Imidazotetrazine Prodrugs. Pharmaceuticals 2014, 7, 797-838. [CrossRef] [PubMed]

5. Bonmassar, L.; Marchesi, F.; Pascale, E.; Franzese, O.; Margison, G.P.; Bianchi, A.; D’Atri, S.; Bernardini, S.; Lattuada, D.; Bonmassar, E.; et al. Triazene compounds in the treatment of acute myeloid leukemia: A short review and a case report. Curr. Med. Chem. 2013, 20, 2389-2401. [CrossRef] [PubMed]

6. Marchesi, F.; Turriziani, M.; Tortorelli, G.; Avvisati, G.; Torino, F.; Vecchis, L.D. Triazene compounds: Mechanism of action and related DNA repair systems. Pharmacol. Res. 2007, 56, 275-287. [CrossRef]

7. Pourahmad, J.; Amirmostofian, M.; Kobarfard, F.; Shahraki, J. Biological reactive intermediates that mediate dacarbazine cytotoxicity. Cancer Chemother. Pharmacol. 2009, 65, 89-96. [CrossRef]

8. Hayward, I.P.; Parson, P.G. Epigenetic effects of the methylating agent 5-(3-dimethyl-1-triazeno)-imidazole-4-carboxamide in human melanoma cells. Aust. J. Exp. Biol. Med. Sci. 1984, 62, 597-606. [CrossRef]

9. Al-Qatati, A.; Aliwaini, S. Combined pitavastatin and dacarbazine treatment activates apoptosis and autophagy resulting in synergistic cytotoxicity in melanoma cells. Oncol. Lett. 2017, 14, 7993-7999. [CrossRef]

10. Naserian, M.; Ramazani, E.; Iranshahi, M.; Tayarani-Najaran, Z. The Role of SAPK/JNK pathway in the synergistic effects of metformin and dacarbazine on apoptosis in Raji and Ramos lymphoma cells. Curr. Mol. Pharmacol. 2018, 11, 336-342. [CrossRef]

11. Finotello, R.; Stefanello, D.; Zini, E.; Marconato, L. Comparison of doxorubicin-cyclophosphamide with doxorubicin-dacarbazine for the adjuvant treatment of canine hemangiosarcoma. Vet. Comp. Oncol. 2015, 15, 25-35. [CrossRef]

12. Song, M.; Zhang, R.; Wang, X. Nano-titanium dioxide enhanced biosensing of the interaction of dacarbazine with DNA and DNA bases. Mater. Lett. 2006, 60, 2143-2147. [CrossRef]

13. Shen, Q.; Wang, X.; Fu, D. The amplification effect of functionalized gold nanopar-ticles on the binding of anticancer drug dacarbazine to DNA and DNA bases. Appl. Surf. Sci. 2008, 255, 577-580. [CrossRef]

14. Matejczyk, M.; Świsłocka, R.; Golonko, A.; Lewandowski, W.; Hawrylik, E. Cytotoxic, genotoxic and antimicrobial activity of caffeic and rosmarinic acids and their lithium, sodium and potassium salts as potential anticancer compounds. Adv. Med. Sci. 2008, 63, 14-21. [CrossRef]

15. Jabłońska-Trypuć, A.; Świderski, G.; Krętowski, R.; Lewandowski, W. Newly synthesized doxorubicin complexes with selected metals-Synthesis, structure and anti-breast cancer activity. Molecules 2017, 22, 1106. [CrossRef] 
16. Trynda-Lemiesz, L.; Śliwińska-Hill, U. Kompleksy metali w terapii nowotworowej. Teraźniejszość i przyszłość. J. Oncol. 2011, 61, 465-474.

17. Kumari, T.; Shukla, J.; Joshin, S. Study on the complex formation and anticancer effect of complex, zinc(II)-dacarbazine. Int. J. Chem. Sci. 2011, 9, 1751-1762.

18. Shukla, J.; Pitre, K.S. Role of bio-metal Fe(III) in anticancer effect of dacarbazine. Indian J. Physiol. Pharmacol. 1998, 42, 223-230.

19. Temerk, Y.; Ibrahim, H.I. Binding mode and thermodynamic studies on the interaction of the anticancer drug dacarbazine and dacarbazine-Cu(II) complex with single and double stranded DNA. J. Pharm. Biomed. Anal. 2014, 95, 26-33. [CrossRef]

20. Lewandowski, W.; Kalinowska, M.; Lewandowska, H. The influence of metals on the electronic system of biologically important ligands, Spectroscopic study of benzoates, salicylates, nicotinates and isoorates. Review. J. Inorg. Biochem. 2005, 99, 1407-1423. [CrossRef]

21. Koczoń, P.; Hrynaszkiewicz, T.; Świsłocka, R.; Samsonowicz, M.; Lewandowski, W. Spectroscopic (Raman, FT-IR and NMR) study of alkaline metal nicotinates and isonicotinates. Vib. Spectrosc. 2003, 33, 215-222. [CrossRef]

22. Lewandowska, M.; Janowski, A.; Lewandowski, W. Spectroscopic Investigations on Lanthanide Complexes with Salicylic Acid. Can. J. Spectr. 1984, 29, 87-92.

23. Lewandowski, W.; Kalinowska, M.; Lewandowska, H. The influence of halogens on the electronic system of biologically important ligands. Spectroscopic study of halogenobenzoic acids, halogenobenzoates and 5-halogenouracils. Review. Inorg. Chim. Acta 2005, 358, 2155-2166. [CrossRef]

24. Koczoń, P.; Piekut, J.; Borawska, M.; Lewandowski, W. Vibrational structure and antimicrobial activity of selected isonicotinates, potassium picolinate and nicotinate. J. Mol. Struct. 2003, 651-653, 651-656. [CrossRef]

25. Kalinowska, M.; Borawska, M.; Świsłocka, R.; Piekut, J.; Lewandowski, W. Spectroscopic (IR, Raman, UV, ${ }^{1} \mathrm{H}$ and ${ }^{13} \mathrm{C}$ NMR) and microbiological studies of $\mathrm{Fe}(\mathrm{III}), \mathrm{Ni}(\mathrm{II}), \mathrm{Cu}(\mathrm{II}), \mathrm{Zn}(\mathrm{II})$ and $\mathrm{Ag}(\mathrm{I})$ picolinates. J. Mol. Struct. 2007, 834-836, 419-425. [CrossRef]

26. Świderski, G.; Świsłocka, R.; Łyszczek, R.; Wojtulewski, S.; Samsonowicz, M.; Lewandowski, W. Thermal, spectroscopic, X-ray and theoretical studies of metal complexes (sodium, manganese, copper, nickel, cobalt and zinc) with pyrimidine-5-carboxylic and pyrimidine-2-carboxylic acids. J. Therm. Anal. Calorim. 2019, 138, 2813-2837. [CrossRef]

27. Świderski, G.; Wojtulewski, S.; Kalinowska, M.; Świsłocka, R.; Wilczewska, A.Z.; Pietryczuk, A.; Cudowski, A.; Lewandowski, W. The influence of selected transition metal ions on the structure, thermal and microbiological properties of pyrazine-2-carboxylic acid. Polyhedron 2020, 175, 114173. [CrossRef]

28. Świderski, G.; Łyszczek, R.; Wojtulewski, S.; Kalinowska, M.; Świsłocka, R.; Lewandowski, W. Comparison of structural, spectroscopic, theoretical and thermal properties of metal complexes ( $\mathrm{Zn}, \mathrm{Mn}$ (II), Cu (II), Ni (II) and Co (II)) of pyridazine-3carboxylic acid and pyridazine-4-carboxylic acids. Inorg. Chim. Acta 2020, 512, 119865. [CrossRef]

29. Świderski, G.; Kalinowska, M.; Wilczewska, A.Z.; Malejko, J.; Lewandowski, W. Lanthanide complexes withpyridinecarboxylic acids-Spectroscopic and thermal studies. Polyhedron 2018, 150, 97-109. [CrossRef]

30. Świderski, G.; Kalinowska, M.; Rusinek, I.; Samsonowicz, M.; Rzączyńska, Z.; Lewandowski, W. Spectroscopic (IR, Raman) and thermogravimetric studies of 3d-metal cinchomeronates and dinicotinates. J. Therm. Anal. Calorim. 2016, 126, 1521-1532. [CrossRef]

31. Świderski, G.; Lewandowska, H.; Świsłocka, R.; Wojtulewski, S.; Siergiejczyk, L.; Wilczewska, A.Z.; Misztalewska, I. Spectroscopic (IR, Raman, NMR), thermal and theoretical (DFT) study of alkali metal dipicolinates $(2,6)$ and quinolinates $(2,3)$. Arab. J. Chem. 2019, 12, 4414-4426. [CrossRef]

32. Padnya, P.; Shibaeva, K.; Arsenyev, M.; Baryshnikova, S.; Terenteva, O.; Shiabiev, I.; Khannanov, A.; Boldyrev, A.; Gerasimov, A.; Grishaev, D.; et al. Catechol-Containing Schiff Bases on Thiacalixarene: Synthesis, Copper (II) Recognition, and Formation of Organic-Inorganic Copper-Based Materials. Molecules 2021, 26, 2334. [CrossRef]

33. Colombo, A.; Dragonetti, C.; Roberto, D.; Fagnani, F. Copper complexes as alternative redox mediators in dye-sensitized solar cells. Molecules 2021, 26, 194. [CrossRef]

34. Pessoa, J.C.; Correia, I. Misinterpretations in Evaluating Interactions of Vanadium Complexes with Proteins and Other Biological Targets. Inorganics 2021, 9, 17. [CrossRef]

35. Soldatović, T. Mechanism of Interactions of Zinc(II) and Copper(II) Complexes with Small Biomolecules. In Basic Concepts Viewed from Frontier in Inorganic Coordination Chemistry; IntechOpen: London, UK, 2018.

36. De Souza, I.C.A.; De Souza Santana, S.; Gómez, J.G.; Guedes, G.P.; Madureira, J.; De Ornelas Quintal, S.M.; Lanznaster, M. Investigation of cobalt(iii)-phenylalanine complexes for hypoxia-activated drug delivery. Dalton Trans. 2020, 49, 16425-16439. [CrossRef]

37. Gaussian; Version 9, Revision A.02; Gaussian Inc.: Wallingford, CT, USA, 2016.

38. Krygowski, T.M.; Cyrański, M. Separation of the energetic and geometric contributions to the aromaticity. Part IV. A general model for thep-electron systems. Tetrahedron 1996, 52, 10255-10264. [CrossRef]

39. Bird, C. A new aromaticity index and its application to fivemembered ring heterocycles. Tetrahedron 1985, 41, 1409-1414. [CrossRef]

40. Weinhold, F.; Landis, C.R. Natural bond orbitals and extensions of localized bonding concepts. Chem. Educ. Res. Pract. 2001, 2, 91-104. [CrossRef]

41. Humphrey, W.; Dalke, A.; Schulten, K. VMD: Visual molecular dynamics. J. Mol. Graph. 1996, 14, 33-38. [CrossRef] 
42. Morris, G.M.; Huey, R.; Lindstrom, W.; Sanner, M.F.; Belew, R.K.; Goodsell, D.S.; Olson, A.J. Software news and updates AutoDock4 and AutoDockTools4: Automated docking with selective receptor flexibility. J. Comput. Chem. 2009, 30, $2785-2791$. [CrossRef]

43. Dassault Systèmes. Biovia Discovery Studio Modeling Environment; Dassault Systèmes Biovia: San Diego, CA, USA, 2016; Available online: https:/ / www.3ds.com/products-services/biovia/products/molecular-modeling-simulation/biovia-discovery-studio/ (accessed on 13 June 2021).

44. Pettersen, E.F.; Goodard, T.D.; Huang, C.C.; Couch, G.S.; Greenblatt, D.M.; Meng, E.C.; Ferrin, T.E. UCSF Chimera-A visualization system for exploratory research and analysis. J. Comput. Chem. 2004, 25, 1605-1612. [CrossRef] [PubMed]

45. Gunasekaran, S.; Kumaresan, S.; Arunbalaji, R.; Anand, G.; Srinivasan, S. Density functional theory study of vibrational spectra, and assignment of fundamental modes of dacarbazine. J. Chem. Sci. 2008, 120, 315-324. [CrossRef]

46. Freeman, H.C.; Hutchinson, N.D. The crystal structure of the anti-tumor agent 5-(3,3-dimethyl-1-triazenyl) imidazole-4carboxamide. Acta Crystall. Sec. B 1979, 35, 2051-2054. [CrossRef]

47. Freeman, H.C.; Hutchinson, N.D. The crystal structures of two copper(II) complexes of the antitumor agent 5-(3,3-dimethyl-1triazenyl) imidazole-4-carboxamide. Acta Crystall. Sec. B 1979, 35, 2045-2050. [CrossRef]

48. Świderski, G.; Wilczewska, A.Z.; Świsłocka, R.; Kalinowska, M.; Lewandowski, W. Spectroscopic (IR, Raman, UV-Vis) study and thermal analysis of 3d-metal complexes with 4-imidazolecarboxylic acid. J. Therm. Anal. Calorim. 2018, 134, 513-525. [CrossRef]

49. Fukui, K. Role of frontier orbitals in chemical reactions. Science 1982, 218, 747-754. [CrossRef]

50. Parr, R.G.; Szentpály, L.V.; Liu, S. Electrophilicity Index. J. Am. Chem. Soc. 1999, 121, 1922-1924. [CrossRef]

51. Samsonowicz, M. Molecular structure of phenyl- and phenoxyacetic acids-Spectroscopic and theoretical study. Spectrochim. Acta A 2014, 118, 1386-1425. [CrossRef]

52. Ahmad, I.; Ahmad, M. Dacarbazine as a minor groove binder of DNA: Spectroscopic, biophysical and molecular docking studies. Int. J. Biol. Macromol. 2015, 79, 193-200. [CrossRef]

53. Wang, X.; Li, Y.; Gong, S.; Fu, D. A spectroscopic study on the DNA binding behavior of the anticancer drug dacarbazine. Spectrosc. Lett. 2002, 35, 751-756. [CrossRef]

54. Radi, A.E.; Eissa, A.; Nassef, H.M. Voltammetric and spectroscopic studies on the binding of the antitumor drug dacarbazine with DNA. J. Electroanal. Chem. 2014, 717-718, 24-28. [CrossRef] 